
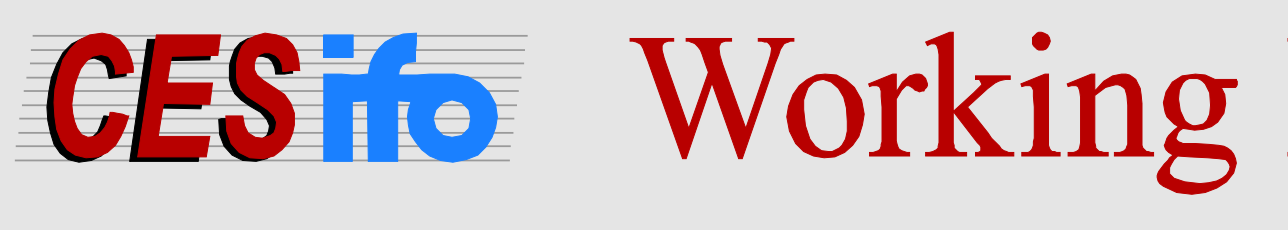

Papers

www.cesifo.org/wp

\title{
Sustainability of German Fiscal Policy and Public Debt: Historical and Time Series Evidence for the Period 1850-2010
}

\author{
Heiko T. Burret \\ Lars P. Feld \\ Ekkehard A. Köhler
}

CESIFO WORKING PAPER NO. 4135

CATEGORY 1: PUBliC FINANCE

FEBRUARY 2013

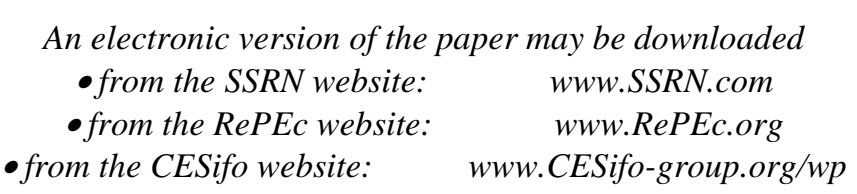




\title{
Sustainability of German Fiscal Policy and Public Debt: Historical and Time Series Evidence for the Period 1850-2010
}

\begin{abstract}
In the last decades, the majority of OECD countries has experienced a continuous increase in public debt. The European debt crisis has prompted a fundamental re-evaluation of public debt sustainability and the looming threat of sovereign debt default. Due to a multitude of large scale events in its past, Germany is far from being an exception: In fact, Germany’s peacetime debt-to-GDP (Gross Domestic Product) ratio has never been higher.

In this paper, we analyse the sustainability of Germany's public finances against the standard theoretical back-ground using a unique database, retrieved from multiple sources covering the period from 1850 to 2010. Multiple currency crises and external events offer anecdotal evidence, contradicting the historical perception of Germany as the poster child of European public finance. Given these corresponding breaks in time series, the empirical analysis is conducted for the subperiods 1872-1913 and 1950-2010. In addition to an anecdotal his-torical analysis, we conduct formal tests on fiscal sustainability, including tests on stationarity and cointegration and the estimation of Vector Autoregression (VAR) and Vector Error Correction Models (VECM). While we cannot reject the hypothesis that fiscal policy was sustainable in the period before the First World War, the tests allow for a rejection of the hypothesis of fiscal sustainability for the period from 1950 to 2010. This evidence leads to the conclusion that Germany's public debt is in dire need of consolidation. Albeit a much needed reform, the incompleteness of the German debt brake will have to be addressed in the coming years, in order to ensure that fiscal consolidation actually takes place.
\end{abstract}

JEL-Code: H620, H630.

Keywords: public debt, sustainability, time series analysis.

Heiko T. Burret

Walter Eucken Institute

Goethestrasse 10

Germany - 79100 Freiburg

burret@eucken.de
Lars $P$. Feld

Walter Eucken Institute

and Albert-Ludwigs-University Freiburg

Goethestrasse 10

Germany - 79100 Freiburg

feld@eucken.de

Ekkehard A. Köhler

Walter Eucken Institute

Goethestrasse 10

Germany - 79100 Freiburg

koehler@eucken.de 
Experience, however, shows that neither a State nor a Bank ever have had the unrestricted power of issuing paper money without abusing that power.

DAVID RICARDO (1817/1932: ch. XXVII)

\section{INTROdUCtion: SOVEREIGN DEBT AS A RECURRING ISSUE IN ECONOMICS}

Sovereign debt sustainability has attracted attention in the wake of the Great Recession and its European sibling, the Euro crisis. Both events have painfully reconfirmed the negative effects of the growing costs of servicing an ever increasing amount of public debt on economic growth, monetary stability and public finance. Despite having a seemingly sound economy when compared with its crisis-ridden southern European periphery Germany, too, may account for unsustainable government finances. German debt-to-GDP (Gross Domestic Product) ratio has never been higher during peacetime; the six year average increase in nominal debt has only been outperformed once - during the German hyperinflation. A unique database, retrieved from multiple sources covering the period from 1850 to 2010, provides us with anecdotal and empirical evidence that rejects the hypothesis of German fiscal sustainability - at least for the period after the Second World War. Therefore, we support a fiscal consolidation strategy and refute the perception that German fiscal policy is on a sustainable path.

A strategy towards fiscal sustainability is helpless, if it is not enmeshed in a broader perspective of public choice that addresses the relevance of non-economic factors on fiscal policy and public debt. The increased academic attention on the effects of institutions on public debt re-affirms the methodological individualistic approach to public finance, resting on the insight that public debt cannot be explained solely by economic factors, wars or extraordinary situations. Beginning with the seminal work of Buchanan and Tullock (1962), the problem of the fiscal commons is crucial for understanding excessive public spending and debt: While the benefits of government spending are concentrated on a privileged group, the costs are spread across all taxpayers, either through taxes or through debt. While the marginal burden of an additional Euro of public spending is hardly noticed by the average taxpayer, the beneficiaries of public spending projects observe a considerable increase in their utility. The citizens thus demand government services up to the point at which their marginal utility obtained from an additional Euro of spending coincides with the marginal costs incurred by additional taxation (Weingast et al. 1981, von Hagen and Harden 1995, Velasco 2000, Schaltegger and Feld 2009a). Government spending is subsequently increased and public revenues (fiscal commons) are overused. There is evidence that competitive fiscal federalism (Schaltegger and Feld 2009b, Baskaran 2010), debt brakes (Feld and Kirchgässner 2008, Krogstrup and Wälti 2008) and fiscal referenda (Feld and Kirchgässner 2001) restrict the fiscal commons problem and thus public debt. 
In addition, a monetary authority may restrain fiscal policy by its commitment to an ex-ante set monetary policy objective. If the central bank' task is to curb money supply growth, the legislative and the fiscal authorities will anticipate that deficits will not be offset by inflation (Sargent and Wallace 1981). Credibly committed to an inflation target - in addition with central bank independence can found a hard budget constrain (Neck and Sturm 2008). The interdependency between public finance and price stability is central to Germany's historical debt record and has received increasing attention in the recent EU debt crisis. Our anecdotal analysis of the determinants of public debt in Germany pays some attention to institutional changes, especially in regards to the different forms of fiscal federalism and monetary regimes during the last 160 years.

Aside from anecdotal evidence, the paper follows a second approach. By conducting a time series analysis of public debt, deficits, expenditures and revenues, it also contributes to the empirical research on fiscal sustainability in Germany. In contrast to previous empirical studies, we cover the time period from the formation of the German Empire up to 2010. The results then point to the importance of the German debt brake.

Following this twofold objective, we are conducting an analysis of the sustainability of public finances in Germany. The remainder of this paper is organized as follows: Section 2 draws on some theoretical considerations regarding fiscal sustainability and reviews empirical studies. In Section 3, anecdotal evidence on the development of German public debt and the relation between economic growth and interest rates is provided. Section 4 presents the empirical strategy and the results. Section 5 , finally, concludes the paper.

\section{Theoretical Framework AND EMPIRICAl Literature ReVIeW}

Most studies on fiscal sustainability are based on the same approach, derived from the Government Budget Constraint (GBC). The GBC requires that across time ( $t$ ), public revenues from taxes $\left(T_{t}\right)$ and from borrowing $\left(D_{t}\right)$ must equal expenditures on goods and services $\left(G_{t}\right)$ and the amortization of the previous year's debt, including interest payments $\left(\left[1+\mathrm{i}_{\mathrm{t}}\right]^{*} \mathrm{D}_{\mathrm{t}-1}\right)$. Assuming that only one-year government bonds are issued with a strictly positive nominal interest rate $(i>0)$, the static GBC can be written as:

$$
T_{t}+D_{t}=G_{t}+\left(1+i_{t}\right) * D_{t-1}
$$

By rearranging (1), it can be shown that the change in nominal debt $\left(D_{t}\right)$ equals the budget balance. $A$ positive term on the right hand side of equation (2) indicates a budget deficit while a negative term indicates a budget surplus. 


$$
D_{t}=G_{t}-T_{t}+\left(1+i_{t}\right) * D_{t-1}
$$

The difference between government spending $\left(G_{t}\right)$ and tax revenues $\left(T_{t}\right)$ is often referred to as the primary balance $\left(P_{t}\right)$. Hence, eq. (2) simplifies to:

$$
D_{t}=P_{t}+\left(1+i_{t}\right) * D_{t-1}
$$

According to Domar (1944: 789) public debt is sustainable - or in his own words "within manageable limits" - if the rate of GDP growth exceeds, or is at least equal to, the growth rate of public debt. Hence, prolonged fiscal deficits alone do not necessarily imply unsustainable public finances. To embed GDP in (3), let $t_{t}$ be the ratio of tax revenue to GDP, $g_{t}$ the ratio of government spending on goods and services to GDP and $d_{t}$ the ratio of debt to GDP, in period $t$ in each case. This leads to eq. (4):

$$
d_{t}=p_{t}+\frac{1+i_{t}}{1+Y_{t}} * d_{t-1}
$$

The primary budget balance to GDP ratio is denoted by $p_{t}=g_{t}-t_{t}$, and the nominal growth rate of GDP by $Y_{t}$. Equation (4) indicates that an increase in the public debt ratio $\left(d_{t}\right)$ is expected when the government runs a fiscal deficit $\left(p_{t}>0\right)$ and the nominal interest rate simultaneously exceeds the rate of nominal GDP growth, $i_{t}>Y_{t}$. Such a situation is unsustainable in the long run. This can be shown by iterating (4) forward and assuming constant interest and growth rates: ${ }^{1}$

$$
\begin{array}{r}
d_{T}=p_{T}+\frac{1+r}{1+y} * p_{T-1}+\ldots+\left(\frac{1+r}{1+y}\right)^{T-1} * p_{1}+\left(\frac{1+r}{1+y}\right)^{T} * d_{0} \\
\text { where } 1+r=\frac{1+i}{1+\pi}
\end{array}
$$

$y$ denotes real GDP growth, $r$ is the real interest rate and $\pi$ is the rate of inflation. Eq. (5) reveals that, in a situation where $p_{t}>0$ and $r>y$, an ever increasing amount of debt must be issued in order to repay legacy debt and finance interest payments. At some point, depending on market expectations, creditors start questioning the government's capability to service its debt and thus restrict their credit supply. Hence, the ability to roll over public debt is temporally restricted. In contrast, given that the growth rate of the economy exceeds the interest rate in the long run, the government is able to roll over its debt. In this constellation, referred to as a Ponzi scheme, GDP growth finances government debt in the long-run.

\footnotetext{
${ }^{1}$ The presentation basically follows Balassone and Franco (2000) and Blanchard and Illing (2006, ch. 26).
} 
Thus, governments are bound by an intertemporal budget constraint, in addition to the static GBC. Assuming that equation (5) holds for every period, the Present Value Budget Constraint (PVBC) is given by:

$$
d_{0}=-\sum_{t=1}^{\infty}\left(\frac{1+y}{1+r}\right)^{t} * p_{t}+\lim _{T \rightarrow \infty}\left(\frac{1+y}{1+r}\right)^{T} * d_{T} .
$$

Equation (6) implies two complementary conditions for a sustainable fiscal policy to hold in equilibrium. A first condition is met when the second term on the right hand side, the discounted present value of the public debt ratio, approaches zero in infinity. If this transversality condition

$$
\lim _{T \rightarrow \infty}\left(\frac{1+y}{1+r}\right)^{T} * d_{T}=0
$$

holds, governments cannot run a Ponzi scheme in the long run. Since the discount factor of future public debt ratios depends on the real interest rate and the real growth rate of the economy, these two variables are crucial in determining the sustainability of fiscal policy. Hence, under the usual assumption that the interest rate exceeds GDP growth, a necessary and sufficient condition for eq. (7) to hold is that the real interest rate is not exceeded by the growth rate of the public debt ratio (Kirchgässner and Prohl 2008, Kitterer 2007).

Bohn (1995: 260) shows that, in a Lucas (1978) exchange economy with infinitely lived agents, governments cannot run a Ponzi scheme. Hence, the discounted present value of public debt converges to zero in infinity and the first condition for fiscal sustainability is met. This implies a second condition, given by a new PVBC:

$$
d_{0}=-\sum_{t=1}^{\infty}\left(\frac{1+y}{1+r}\right)^{t} * p_{t}
$$

Eq. (8) requires that the discounted future primary budget ratios are equal to the current public debt ratio. This implies that public finances are sustainable when offset by sufficient future surpluses. However, as discussed above, such a restriction is not necessary if a growing debt burden can be financed through sufficient economic growth (Domar 1944). The possibility of "outgrowing one's debt" without having ever achieved any primary surpluses is only feasible if the real interest rate is below the real growth rate of GDP in the long run. Similar to eq. (8), Generational Accounting, as introduced by Auerbach et al. $(1991,1992)$, defines the intertemporal budget constraint as the net present value amount that current and future generations are projected to pay to the government now and in the future (1991: 55). 
The two complementary definitions of fiscal sustainability derived from the PVBC of eq. (6) are testable in empirical research. One line of empirical studies tests whether the transversality condition (eq. 7) holds, by conducting stationarity tests for public debt and deficits, respectively. If the transversality condition equals zero, public finances are expected to be stationary, i.e., sustainable. This approach was used in one of the first empirical studies on the sustainability of public finances, conducted by Hamilton and Flavin (1986). By applying stationarity tests to US public debt and deficits in the period 1962-1984, they conclude that the transversality condition holds, i.e., that U.S. fiscal policy is sustainable. ${ }^{2}$

The second research approach requires current public debt to equal the discounted future primary budget surpluses (eq. 8). This line of empirical testing follows a methodology proposed by Engle and Granger (1987) and Johansen (1988). They suggest that time series which are individually integrated of order one, i.e., I(1), but at the same time have a linear combination of a lower order of integration, i.e., I(0), are cointegrated. This implies that a long-run equilibrium can be established and short-run deviations from the equilibrium can be represented by a Vector Error Correction Model (VECM). Adapted to fiscal sustainability, a cointegration between public debt and budget surpluses or between public revenues and expenditures, with a cointegration vector of $[1,-1]$, is assumed to lead to sound finances. Early studies in this line of research include Elliot and Kearney (1988), Hakkio and Rush (1991), Smith and Zin (1991), MacDonald (1992), Tanner and Liu (1994), Liu and Tanner (1995), Ahmed and Rogers (1995), Haug (1995) and Quintos (1995).

The stationarity (unit root) and cointegration tests have been criticized by Bohn $(1995,1998)$ for their strong assumptions regarding the discount rate and fiscal projections. Bohn shows that sustainable finances in a world of certainty might be considered unsustainable under uncertainty. Additionally, results obtained by previous methods are partly not robust to changes in the number of lags. He further argues that unit root tests ignore systematic components and can at best capture "ad-hoc sustainability", i.e., the satisfaction of the PVBC. For instance, budget deficits due to tax smoothing should be allowed to take place. Therefore, Bohn proposes to test whether the reaction of the primary surplus to GDP ratio is sufficient to offset changes in the public debt to GDP ratio. If the latter holds, i.e., surplus increases at least linearly with debt, public finances are sustainable.

The first analysis of German public finances was presumably conducted by Grilli (1988). Using data for a period from the early 1950s to 1986, he concludes that the hypothesis of non-stationarity (unsustainable) fiscal deficits can be rejected. While most subsequent studies basically apply similar approaches, the findings are not unambiguous (see Afonso 2005 for an overview). Since the late

\footnotetext{
${ }^{2}$ Notable subsequent stationarity tests for the U.S. debt and deficits have been conducted by Kremers (1988), Trehan and Walsh (1988, 1991) and Wilcox (1989). Other empirical tests on the sustainability of the U.S. finances have been performed by Haug (1995), Bohn (1998, 2008), Greiner and Kauermann (2007) and Polito and Wickens (2011).
} 
1990s, the German debate has been enhanced by the results of cointegration tests, predominantly providing evidence in support of the hypothesis of fiscal sustainability (e.g., Payne 1997, Bravo and Silvestre 2002, Afonso 2005). By applying the method proposed by Bohn $(1995,1998)$, Greiner et al. (2006) and Greiner and Kauermann (2007) conclude that public finances in Germany are basically sustainable. Similar conclusions are offered by Greiner and Kauermann (2008). They perform semiparametric tests using penalized spline smoothing. Polito and Wickens (2011) find contrary results by analysing the fiscal adjustments required to reach a targeted debt ratio and by testing for stationarity. Unit root tests are also used by Kitterer (2007) in order to analyse the finances of the German states. He concludes that fiscal policy does not comply with the PVBC in 13 out of 16 states.

In contrast to the above-mentioned studies, this paper focuses on a much longer time span (18722010) and applies a more in-depth analysis of the sustainability of German public finance. In fact, we apply a wide range of approaches and tests, including various stationarity tests (partly allowing for structural breaks), cointegration tests, VAR tests as suggested by Bohn $(1995,1998)$ and the estimation of a VECM. While previous studies focus mainly on one period, we additionally cover different sub-periods, thus allowing for period-specific peculiarities in German fiscal policy. Furthermore, our approach differs from previous studies by performing statistical tests for all four indicators of fiscal policy, i.e., public revenue, expenditure, deficit and debt. ${ }^{3}$ In consequence, this paper contributes to existing empirical literature by providing a thorough and extensive analysis of German fiscal policy since 1872. In addition to empirical evidence, anecdotal evidence is drawn upon to arrive at a more complete understanding of the development of German public debt.

\section{History of Public Debt in Germany 1850-2010: Anecdotal Evidence}

Before formally testing the sustainability of German public finances, it is useful to consider Germany's fiscal history. Figure 1 illustrates the development of German public debt from 1850 to 2010. This time span can be divided into four separate phases: The first phase spans from 1850 to 1870 and it is characterized by relatively steady levels of sovereign debt on the one hand and changing governance structures on the other. The second phase describes the peaceful era of the German Empire leading up to World War I, the so called Kaiserreich (1872-1913). According to Obstfeld and Taylor (2003), the first two phases coincide with the first era of globalization (1850-1913). The third phase includes the two World Wars and their aftermaths, each culminating in a severe debt crisis and currency reform (1923 and 1948; see also Figure 2). The fourth phase starts with the founding of the Federal Republic of Germany and comprises large scale events as the collapse of the Bretton Woods

\footnotetext{
${ }^{3}$ Indeed, Afonso and Jalles (2011) analyse a similar period (1880-2009), yet they almost exclusively apply stationarity tests regarding public debt levels, only. In addition, they do not focus on different sub-periods.
} 
system, the German Reunification and the Great Recession. The fourth phase coincides with the second era of globalization.

Figure $1 \quad$ Public Debt as Percentage of GDP in Germany, 1850-2010

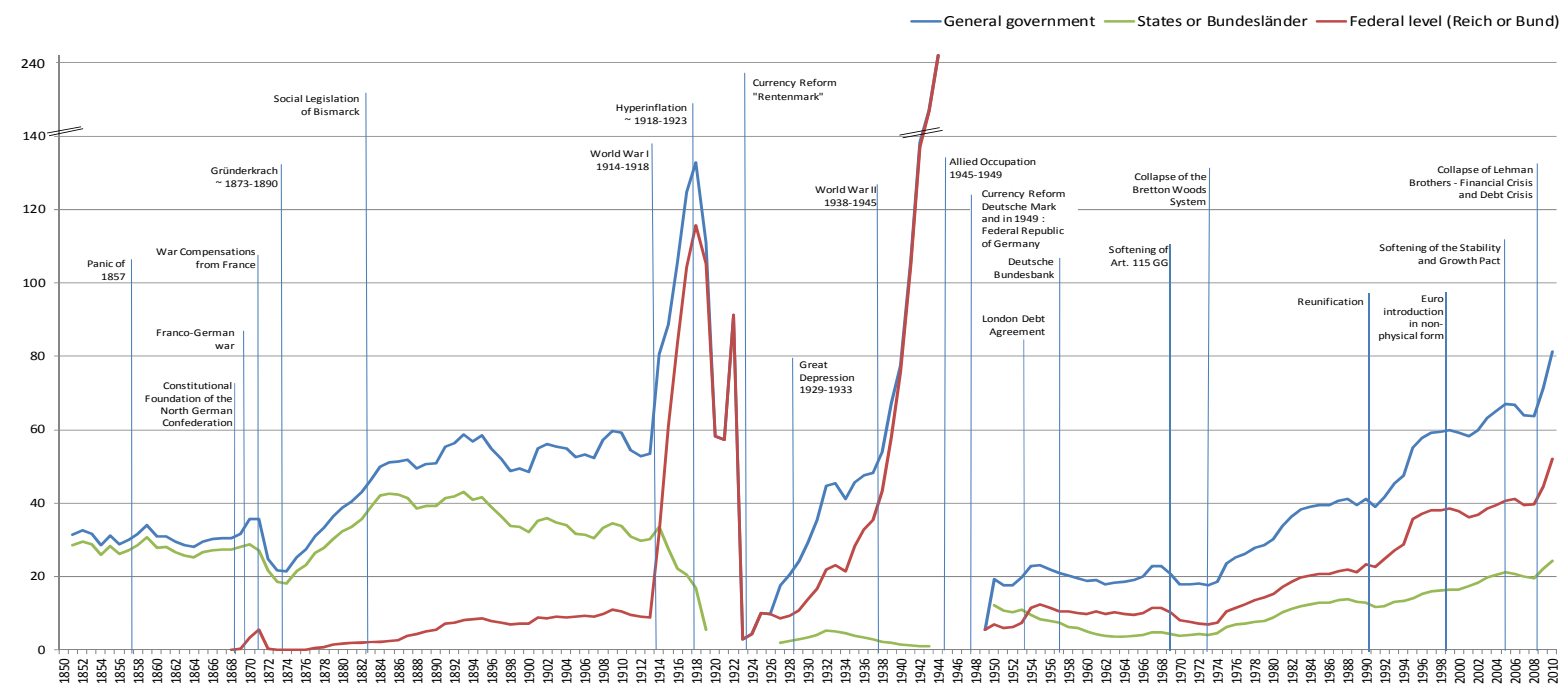

Missing data: 1945-1948; for 1920-1926 and 1944-1949 no data for states; for 1915-1926 and 1940-1945 no data for municipalities. Before 1949 fiscal year ends $31^{\text {st }} \mathrm{March} / 1^{\text {st }}$ April. The reference date for 1923 is $15^{\text {th }}$ November. 1945 debt refers to the level at the end of World War II. General government data includes federal, state and local tiers; since 1954, it includes Federal Special Funds; since 2006, it includes most, and since 2010, all public funds, institutions and companies. Federal level data includes the Mefo bills for 1932-1944. For further details refer to data sources listed in Appendix A.1.

\subsection{Phase I: Debt and Fiscal Policy in the (North-) German Confederation (1850-1870)}

Following the unsuccessful attempt to establish a German nation state in the wake of the so-called March-Revolution of 1848 , federal government debt did not accrue due to the mere lack of a central government. Public debt was, however, not non-existent: The sovereign states of the German Confederation (Deutsche Bund) had run fiscal deficits even before the starting point of our analysis (Figure 1). While debt statistics for most states are only available sporadically, coherent data series on public debt can be retrieved for the larger states such as Prussia, Bavaria, Saxony and Baden. ${ }^{4}$ In 1851, the aggregated debt-to-GDP ${ }^{5}$ ratio of these states was 30 percent. This debt can be explained by the fiscal burden of the Napoleonic Wars. However, in comparison to France (200\%) or the United Kingdom (149\%), German public debt was still relatively low (Abbas et al. 2010). This large difference might have been caused by the debt defaults of several German states, e.g., Prussia in 1807 and 1813, Hesse in 1814, Schleswig-Holstein in 1850 or Westphalia in 1812 (Reinhart and Rogoff 2009). The two decades following the March Revolution of 1848 are characterised by ostensibly sound finances, the only exception being the economic crisis of 1857, which resulted in the Bank of Hamburg receiving a 15 million Marks bail-out from Vienna (Bordo and Schwartz 1999). Besides the relatively

\footnotetext{
${ }^{4}$ The German Empire was later composed of 26 states (including three Hanseatic cities and Alsace-Lorraine). Missing data are derived by interpolation (Hoffmann 1965)..

${ }^{5}$ Before 1913 no consistent data on nominal GDP are available. Instead, GNP was used (see Appendix A.1).
} 
stable debt-to-GDP ratio, the amount of nominal debt had nearly doubled by the time of the foundation of the North German Confederation in July 1867 after the victory over the Habsburg Empire in the Austro-Prussian war in 1866 (Figure 2). ${ }^{6}$ The main tasks of the North German Confederation were to enlarge its navy, to build a costal defence system and, at least partly, to finance the GermanFrench War of $1870 / 71$. Aside from matters of military, bank regulation and the standardization of weights and measures hardly any responsibilities were assigned to the federal level. Nevertheless, beginning in 1868, federal government debt had risen to 692 million Marks in March 1871.

\subsection{Phase II: Struggling Decentralization of Fiscal Policy in the Kaiserreich (1871-1913)}

The Kaiserreich, constituted in April 1871, inherited not only the debt burden of its member states, but also a high degree of political autonomy, a system of bottom-up fiscal federalism and a dominant influence of Prussia. While most of the states were relatively small, Prussia comprised 60 percent of the total population and economic power, and delegated both the Chancellor (Reichskanzler) and the German Emperor (Kaiser). Despite Prussian dominance, the federal states were granted extensive legislative competence, including the power to tax. While the lower chamber of parliament, i.e., the Reichstag, remained rather weak, the Federal Council, i.e., the Bundesrat was the dominant legislative body, having been granted a veto right pertaining to all federal legislation, including taxation and the right to dissolve the Reichstag. Since small states were represented disproportionately strongly in the Bundesrat, they were - at least formally - able to overrule Prussia. In general, the competencies between the federal and the subnational level were clearly assigned, remaining mostly at the state level (Stegarescu 2005).

The high degree of fiscal autonomy allowed for (fiscal) competition between the states. Hence, fiscal responsibility of the jurisdictions was fostered and political incentives to incur debt have been curbed. Due to their political (veto) power the states were relatively successful at obstructing the expansion of central taxation powers. The federal government had to rely on revenues from tariffs (27\%), indirect taxes and matricular contributions (29\%). ${ }^{7}$ The states were obliged to pay for the latter in order to balance the ordinary federal budget. Therefore, the federal government's means of accruing debt were limited. Since matricular contributions were collected in accordance with the state's population, the federal government was highly dependent on the Prussian state (Gerloff 1913). In addition to these contributions, no further fiscal equalization scheme was established.

\footnotetext{
${ }^{6}$ In contrast to the North German Confederation, the German Confederation and German Customs Union (Deutsche Zollverein) were relatively noncommittal unions of sovereign states without a common constitution.

${ }^{7}$ The numbers in parentheses indicate the respective percentages of total federal revenue, excluding debt obligations in 1871.
} 
After receiving war indemnities from France, totalling 4.2 billion Marks, the federal debt was completely paid for in 1874 and regional debt decreased significantly (Gerloff 1913). ${ }^{8}$ This increase in liquidity fuelled economic growth and led to a period known as the Gründerzeit. The Kaiserreich experienced an extraordinary increase in production capacities and the number of companies and banks. Most stock prices in Berlin doubled between 1870 and 1872. It is often argued that the Kaiserreich transitioned from an agricultural to an industrialized country during this time. Although the spoils of war and the consequent boom of the Gründerzeit initially had a stabilising effect on public finances, this stability retarded the progress of fiscal reforms. The existing tax system was not designed to cope with the new structural pattern of the economy, resulting in decreased tax revenues. In 1873 , economic growth slowed down due to global financial turmoil that was described as the Gründerkrach in Germany. This resulted in the most extensive economic crisis of the $19^{\text {th }}$ century in Germany, lasting almost three decades (Plumpe 2010). The subsequent rise in public debt on the regional level (Fig. 1 and 2) is particularly remarkable, as the federal government was, at least in part, able to finance its growing expenditures by collecting higher matricular contributions. To do so, these contributions had to rise by an average of 40 percent during the period from 1874 to 1879 (Gerloff 1913: 522). Though the debt level continued to increase in the years following the Gründerkrach, an international comparison reveals that German public finances were in better shape than those of other countries (Appendix A.3). Nevertheless, a (weak) debt constraint was imposed on the Kaiserreich. While article 73 of the federal constitution of 1871 restricted debt obligations to extraordinary circumstances, i.e., war finance, the law was obviously interpreted quite loosely.

As part of its protectionist trade policy, and in order to improve its finances, the federal government increased tariff rates in 1879. Although central government revenue had doubled by 1887 , the effort was hardly rewarded. In order to prevent fiscal independence by the federal government, the states enacted the so-called Frankenstein Clause in 1879. According to this law, all federal revenues from tariffs and the tobacco tax exceeding 130 million Marks per year (the amount was increased later) had to be transferred to the states (Gesetz betreffend den Zolltarif des Deutschen Zollgebiets und den Ertrag der Zölle und der Tabacksteuer, §8). The excess revenue was deducted from the states' matricular obligations, regardless of potential fiscal deficits at the federal level. The resulting reverse matricular payments (Table 1) may explain the decrease of the debt-to-GDP ratio at the state level in the following decades and, in combination with the armament of the German fleet, the rise of the federal debt-to-GDP ratio (Figure 1).

\footnotetext{
${ }^{8}$ The outstanding debt could be repaid at any time since the Zwangstilgung (coerced coverage) was abolished in 1870 and a freie Tilgung (free principal) established (Neumark 1976). Aside from debt repayment, the indemnities were used in order to obtain gold and subsequently introduce a gold currency.
} 


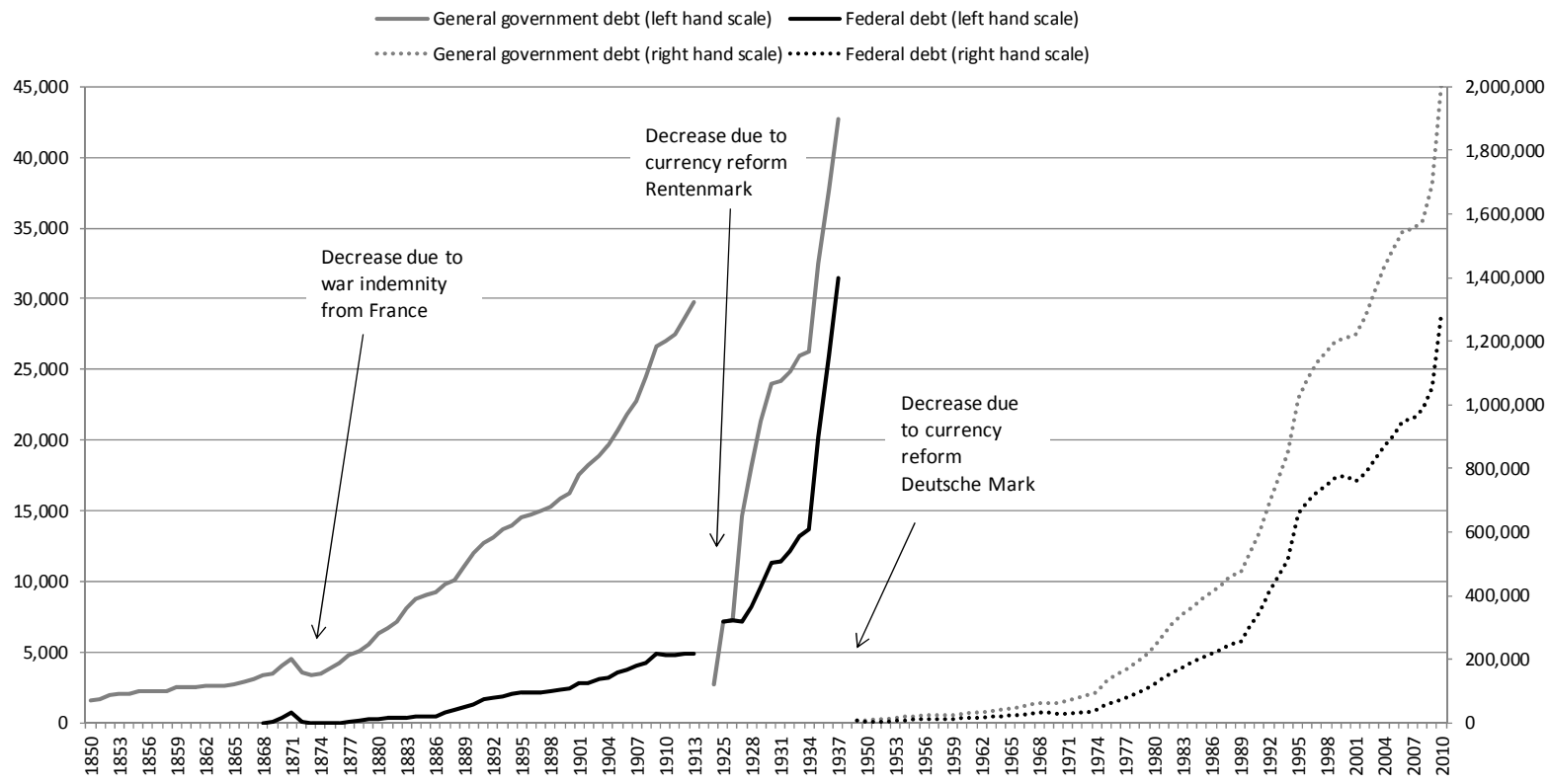

*Public debt in Mark, Reichsmark, Deutsche Mark and Euro, respectively. For further definition and sources, refer to Figure 1. For 19141923 and 1938-45 debt is not mapped due to distortive outliers. For 1945-48 no data are available. 1850-1937 refer to the left hand scale, 1949-2010 refer to the right hand scale.

Table $1 \quad$ Adjusted Matricular Contributions to the Reich (in million Marks)*

\begin{tabular}{rrrrrrrrrr}
\hline $\mathbf{1 8 7 9 / 8 0}$ & $1881 / 82$ & \multicolumn{1}{c}{$1883 / 84$} & $1885 / 86$ & $1887 / 88$ & $1889 / 90$ & $1891 / 92$ & $1893 / 94$ & $1895 / 96$ & $1897 / 98$ \\
\hline 64.1 & 17.2 & -11.5 & -13.0 & -5.4 & -139.8 & -66.9 & 30.3 & -17.4 & -13.2 \\
\hline
\end{tabular}

*The numbers are derived by subtracting the Frankenstein Payments to the states from the matricular contributions to the Reich. Source: Gerloff (1913: 522).

The additional increase in federal debt predating WWI was fuelled by rising colonial and educational expenses from 1885 onwards, the introduction of the social insurance systems by Bismarck (e.g., health insurance in 1883, pensions insurance in 1891) and the costs of war preparations. While the military expenses accounted for roughly 60 percent of total federal expenditures in the pre-war years, this share increased to an average of 86 percent during the war (Table 2). The percentage of social spending increased from an average of 18 percent in 1876-1880 to 31 percent in 1911-1913 (Hefeker 2001). In addition to new functions being assigned to the federal level, the loss of the states' autonomy is also reflected by the introduction of the inheritance tax in 1906, a state tax shared with the Reich, and the Wehrbeitrag (war contribution) in 1913, the first direct tax on the federal level (Neugebauer 2000: 133, Stegarescu 2005). This centralization tendency is accompanied by an increase in public debt, particularly at the federal level. Figure 1 shows that the total public debt-to-GDP ratio increased by 148 percent between 1873 and 1913. As indicated by Figure 2, the amount of total nominal debt rose by 783 percent during this period. Aware of this dramatic increase in public debt, the Reich followed the example of the states and enacted a law specifying that, beginning in 1908, 3-5 percent of federal debt is to be repaid each year. However, the law never really came into effect (Neumark 1976). The state of German public finances provoked a political debate on 
tax reforms, particularly on the introduction of direct federal taxes. Dissent on this matter finally resulted in the resignation of chancellor Bülow in 1909.

Table 2 Ordinary and Extraordinary Expenses of the Reich (in billion Reichsmark)

\begin{tabular}{|c|c|c|c|c|c|}
\hline \multicolumn{2}{|c|}{ Total } & \multicolumn{2}{|c|}{ Military and War } & \multicolumn{2}{|c|}{ Debt Service } \\
\hline 1911 & $2.12(100 \%)$ & 1.28 & $(60.34 \%)$ & 0.27 & $(12.63 \%)$ \\
\hline 1914 & $8.78 \quad(100 \%)$ & 7.76 & $(88.36 \%)$ & 470.4 & $(5.36 \%)$ \\
\hline 1915 & 25.80 (100\%) & 24.06 & (93.22\%) & 1.35 & $(5.22 \%)$ \\
\hline 1917 & $52.20(100 \%)$ & 42.23 & (80.91\%) & 6.52 & (12.49\%) \\
\hline 1918 & $44.43 \quad(100 \%)$ & 33.95 & $(76.42 \%)$ & 6.77 & (15.24\%) \\
\hline 1919 & $53.16(100 \%)$ & *30.64 & (57.64\%) & 8.40 & (15.80\%) \\
\hline
\end{tabular}

* Including fiscal burdens of war consequences, demobilization and reparations. Source: Roesler (1967).

\subsection{Phase III: Two World Wars, Sovereign Defaults and Currency Reforms (1914-1949)}

The amount of debt accumulated in the war years indicates how the war was financed. With the outbreak of WWI, numerous laws with the purpose of enhancing the ability to generate public revenue came into effect. The Reichsbank, not independent in $1914,{ }^{9}$ was finally released from its duty to exchange Marks for gold, implying flexible exchange rates. As a result, the gold standard, which Schumpeter (1952) called "Die goldene Bremse an der Kreditmaschine" (the golden brake on the credit machine) was abolished. Additionally there was a de facto cessation of almost all quantitative restrictions on the money supply (Pfleiderer 1976). These amendments led the government to finance its expenditures directly through the central bank. The rise in short term treasury bills held by the Reichsbank is evidence for the extensive use of this instrument, resulting in an increasing inflation rate (Table 3). Due to the already high inflation rate, neither the introduction of new taxes nor the increase of existing ones could offset the fiscal deficits anymore. In the period between 1912 and the end of WWI, the increase in public debt exceeded the inflation-driven increase in nominal GDP, resulting in an upward shift of the debt-to-GDP ratio. In 1915 the debt-to-GDP ratio and the nominal debt of the central government exceeded the debt level of the states for the first time. Apart from a short time period after WWII, this has not changed up to today (Figure 1).

When the Weimar Republic was established in 1919, Art. 8 of the new constitution restricted the use of public credit to extraordinary needs and the financing of public investments. The crisis and the confusion after the First World War enabled the new Republic to reduce the fiscal and political autonomy of the states in such a way that the Reichstag became the dominant authority. In order to improve public finances, the Erzberger reform of 1919/20 altered the structure of fiscal federalism

\footnotetext{
9 “Die dem Reiche zustehende Leitung der Bank wird vom Reichskanzler...ausgeübt..." (Deutsches Reichsgesetzblatt Vol. 1875, Nr. 15, 177198 , as mended on: $14^{\text {th }}$ March $1875, \S 12$ ). This could be translated to: The administration of the Bank in the powers of the Reich is conducted by the Chancellor (Translation by the authors.).
} 
further towards a more centralized top-down approach. The federal level of government was institutionally supplemented with a financial administration and the authority to levy most taxes, leading to a unification and equalization of regional tax laws. The states were provided with shares of certain tax revenues in order to compensate them for the loss of fiscal autonomy. Furthermore, a vertical equalization scheme was established (Stegarescu 2005). The states were now fiscally dependent on the federal government. The growing federal sector may also explain the evident increase in the share of federal debt (Figure 1).

In 1919/20 the Treaty of Versailles obliged the new Republic, contrary to its own intentions, ${ }^{10}$ to pay reparations to the Entente. Indebtedness and inflation prevented the Weimar Republic from issuing government bonds on the capital markets. ${ }^{11}$ The methods of generating public revenue were limited to taxes and the further (ab)use of the Reichsbank. Although the Erzberger reform led to an increase in various taxes, no substantial revenues could be generated in real terms (Haller 1976). Thus the government had to rely on further increases in the amount of floating debt held by the Reichsbank and in money supply (Table 3). The hyperinflation induced a decrease of the total debt-to-GDP ratio from its high level of 131 percent of GDP in 1918, with an exception in 1922, when the increase in debt exceeded the inflation driven rise in nominal GDP. In 1923, almost 90 percent of state revenue was generated by issuing debt obligations. Due to inflation, the possibility of paying contributions in government bonds and then repurchasing them, the debt-to-GDP ratio approximated zero in $1923 .{ }^{12}$ The debt-to-GDP ratio of the states had already been zero in 1919, as most of their debt had been transferred to the federal level as compensation for the acquisition of the railway (Gesetz betreffend den Staatsvertrag über den Übergang der Staatseisenbahnen auf das Reich, §4).

The hyperinflation ended in November 1923, with the currency reform and the Reichsbank ceasing to discount treasury bills. The newly issued currency, the Rentenmark (backed by real estate, land and later by gold), was exchanged for 1 trillion Marks. While smaller amounts of debt were simply deleted, the majority of outstanding public obligations were transferred according to the principle "Mark für Mark" (Mark for Mark). Thus, public debt was notably reduced. Outstanding liabilities still existed in the form of reparations, which Germany had previously suspended. Negotiations on restructuring these debts resulted in the Dawes Plan of 1924. According to this agreement, Germany had to pay a rate of 2.5 billion Marks per annum, starting in 1928/29. An expiry date was not agreed upon. Discontent of the involved parties and the onset of the Great Depression led to a new agree-

\footnotetext{
${ }^{10}$ In 1916 the State Secretary of the Reich Treasury announced in the Reichstag: "Das Bleigewicht der Milliarden haben die Anstifter dieses Krieges verdient; sie mögen es durch die Jahrzehnte schleppen, nicht wir." (The burden of the billions is the merit of the instigators of this war; they may carry it through the decades, not us. Translation by the authors.) (Helfferich 1916: 224).

${ }^{11}$ Exceptions are some "value stable" bonds expressed in Goldmark, rye or other goods (Pfleiderer 1976).

${ }^{12}$ Since no data on nominal GDP are available for the time period between 1914 and 1924, we had to derive them from real GDP estimates deflated by the respective CPI. The amplitude of our data in 1922 may be due to the fact that CPI is measured at the end of the year, while debt is measured at the end of the fiscal year (i.e., the end of March of the following year). However, our estimated debt-to-GDP ratios are rather similar to those of Holtfrerich (1996) and to data kindly made available by Schularick. For further details see Appendix A.1 and A.2.
} 
ment in 1929. The so-called Young Plan reduced annual payments to 2 billion Marks for the next 59 years. In order to service the payment schemes, Germany issued the Dawes and Young bond, respectively (Glasemann 1993).

Table $3 \quad$ Macroeconomic Indicators, 1915-1923

\begin{tabular}{|c|c|c|c|c|c|c|}
\hline & \multicolumn{3}{|c|}{ Floating debt (in million Marks) } & \multirow{2}{*}{$\begin{array}{l}\begin{array}{l}\text { Money in } \\
\text { circulation }^{\mathbf{1 , 2}}\end{array} \\
1913=1\end{array}$} & \multirow{2}{*}{$\begin{array}{l}\begin{array}{l}\text { Exchange rate } \\
\text { to U.S. Dollar }\end{array}{ }^{2} \\
1914 \text { = parity }\end{array}$} & \multirow{2}{*}{$\begin{array}{l}\begin{array}{l}\text { Consumer } \\
\text { Price Index }\end{array} \\
1913=100\end{array}$} \\
\hline & total & Held by $t$ & chsbank & & & \\
\hline 1915 & 7.2 & 6.0 & $83.33 \%$ & 1.5 & 1.16 & 135 \\
\hline 1916 & 9.3 & 7.3 & $78.49 \%$ & 1.7 & 1.26 & 180 \\
\hline 1917 & 18.5 & 13.1 & $70.81 \%$ & 2.3 & 1.69 & 225 \\
\hline 1918 & 33.0 & 15.7 & $47.58 \%$ & 5.5 & 1.97 & 310 \\
\hline 1919 & 63.7 & 29.9 & $46.94 \%$ & 8.3 & 11.1 & 490 \\
\hline 1920 & 91.5 & 42.7 & $46.67 \%$ & 13.4 & 17.4 & $1^{\prime} 044$ \\
\hline 1921 & 166.3 & 64.5 & $38.79 \%$ & 20.3 & 45.7 & $1 ‘ 337$ \\
\hline 1922 & 271.9 & 146.5 & $53.88 \%$ & 213.0 & $1^{\prime} 808.0$ & $15^{`} 036$ \\
\hline $1923^{3}$ & 191.6tri & 189.8tri. & $99.06 \%$ & $81.8 \mathrm{bn}$. & 1’000bn. & $15^{\prime} 897 \mathrm{bn}$. \\
\hline
\end{tabular}

${ }^{1)}$ Stückgeldumlauf (Reichsbanknoten, Privatbanknoten, Reichskassenscheine, Darlehenskassenscheine and coins), ${ }^{21} 1915-1917$ at mid year, 1918-1922 end of year. ${ }^{3)}$ Until $23^{\text {th }}$ November. Sources: Deutsche Bundesbank (1976) and Haller (1976).

Soon after reparations had been agreed upon, public finances were hit by the Great Depression, placing a high burden on public finances, especially on the local level. Two developments played a major role in this: First, the main sources of local revenue (corporate and personal income tax) decreased by over one third and, second, higher costs of social services caused local expenditures to rise (Petzina 1986: 246-251). Due to the fiscal situation during the Great Depression, the Weimar Republic introduced capital controls in 1931 and stopped servicing most of its debt in compliance with the contracts. The capital controls led to an erosion of the gold standard, which gave the Reichsbank leeway for discretionary monetary policy. After the takeover of the National Socialists in 1933, most debt payments were discontinued, the Reichsrat was dissolved and the federal structure of Germany was factually abolished. Subsequently, the share of federally determined tax revenues increased from 50 percent in 1913/14 to 98 percent in 1938 (Terhalle 1952: 317).

While there was a legal ceiling on the amount of treasury bills discountable at the Reichsbank before 1933, the National Socialists found various ways to circumvent fiscal and other disciplining rules of the Weimar Republic constitution. The rule of the National Socialists can be divided into four stages, each characterised by different methods of public finance. The practice predominantly used during the first stage of the regime (1933-1936) was the issue of bills of exchange by dummy firms redeemable at par in Reichsmark and expansive fiscal policy. The latter was already common before the National Socialists came to power: Job-creating measures were initially introduced in 1930, and their 
intensive use in 1932/1933 was re-financed by tax credits (Schiller 1936: 54). ${ }^{13}$ In addition to these waivers, several shadow and off-budget activities became the backbone of the National Socialist work programme. ${ }^{14}$ The second stage (1936-1939) of National Socialist fiscal policy was directed to install a system of "silent" war financing operations. Wages and prices were frozen in June and November 1936, while money supply was increased. In 1939, the Kriegswirtschaftsverordnung ( $\$ 1$, RGBI. I, 1939, 1609-1613) imposed penalties on the hoarding of money, extending to bank deposits at commercial banks. Consumer demand was capped by the introduction of consumption stamps in September 1939, while the investment operations of banks were limited and restricted to locally issued products. This boosted savings even further. Since commercial banks were prohibited to invest savings abroad (capital controls had been previously established) and were regulated to buy national securities, savings indirectly, but inevitably, ended up at the Reichsbank - or in government bonds. This "silent" war financing procedure turned the German citizens into creditors of the National Socialist war finance strategy. In 1939, by means of the "Gesetz über die deutsche Reichsbank" the bill financing arrangement became obsolete, since public expenditures could now be financed, to a nearly unlimited extent, directly through the Reichsbank (Hansmeyer and Caesar 1976). ${ }^{15}$

The beginning of the third stage (1940-1943) was marked by the occupation of neighbouring countries. Additional revenue was obtained by integrating them into the above mentioned scheme, while selling off their central bank's securities (including their gold) on the still existent international capital market (Vogler et al. 2012). The implementation of subsidiaries of the Reichsbank in Krakow (December 1939), Brussels (June 1940) and Bohemia (August 1940) illustrates the extent of this strategy. The leverage of the war financing operations increased, as more and more citizens were forced into this scheme. The fourth and final stage (1943-1945) saw the capital inflow from the occupied territories slow down. Additionally, the limits of the war financing operations between the Reichsbank and private savings had been reached. The Reichsbank started financing public spending by directly buying bonds and printing money. The cumulated debt overhang and the loss of credibility of the institutions of the Reich finally led to a rejection of the Reichsmark in May 1945.

The pursued strategies of war finance, combined with decreasing economic growth, resulted in a rise of the debt-to-GDP ratio, exceeding 240 percent in 1944 - not including shadow budgets and other liabilities by foreigners (Figure 1). This increase in the debt-to-GDP ratio surpassed the experience of WWI and exceeded the debt-to-GDP ratios of most other nations (Appendix A.3). In contrast to WWI,

\footnotetext{
${ }^{13}$ This included the installation of institutions that financed work programmes, such as the Deutsche Gesellschaft für öffentliche Arbeiten (Oeffa) (e.g., Papen-Programm, Sofort-Programm and the Reinhardt-Programm).

${ }^{14}$ An often cited example is the Metallurgische Forschungsanstalt (Mefo) which was installed to emit bonds to further increase the fiscal power of the Reich. The bonds served as bills of exchange to finance rearmament, while at the same time camouflaging the war preparation from foreign observers (Cohn 1997: 271). In an interrogation, Hjalmar Schacht (1945), president of the Reichsbank from 1933-1939, said about this technique that it "enabled the Reichsbank to lend by a subterfuge to the government what it normally or legally could not do". From a quantitative point of view though, the Mefo bills were not very important (Table 4).

${ }^{15}$ According to the "Gesetz über die deutsche Reichsbank" from June 15, 1939, the Reichsbank was essentially assigned directly to Hitler.
} 
the freezing of prices and wages curbed inflation. A currency reform was enacted in June 1948, three years after the German capitulation (Goldschmidt and Köhler 2008).

Table $4 \quad$ Debt and Money Circulation 1938-1945 (in billion Marks)

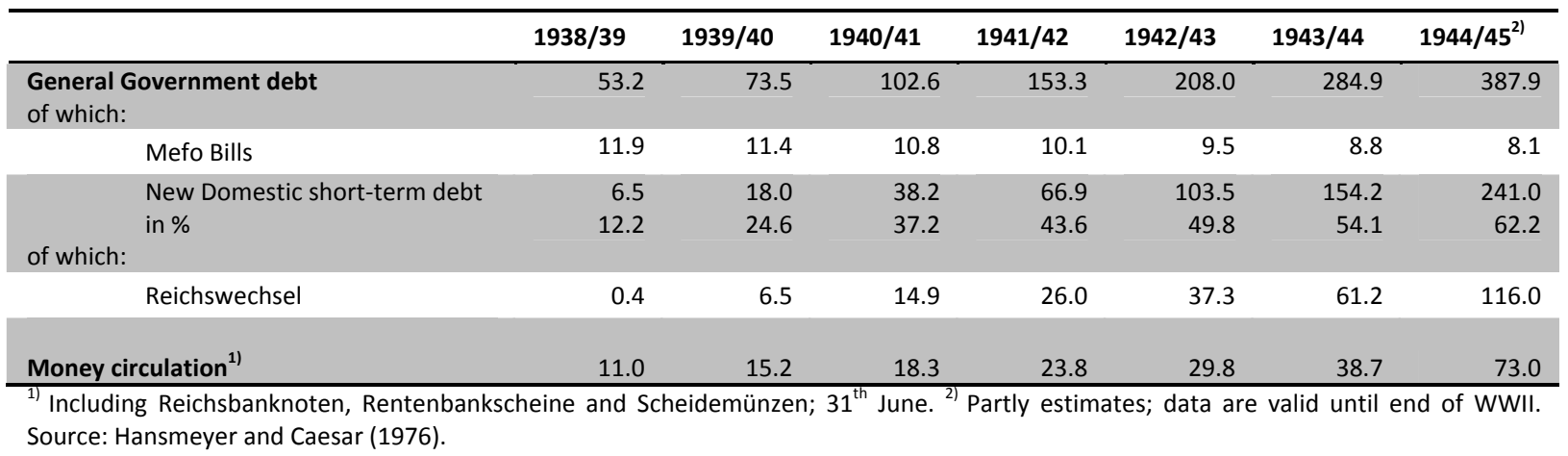

\subsection{Phase IV: Fiscal Policy in the Federal Republic of Germany (1950-2010)}

The currency reform of 1948 went hand in hand with a default on liabilities of the National Socialist regime. The claims of outstanding German debt were not decided and settled before the London Debt Agreement in 1953. By that time, the Bank deutscher Länder (BdL) had already gained autonomy from the Allies and had successfully organized an asset re-allocation (i.e., Ausgleichsforderungen) to maintain the supply of capital and credit from the start of the Deutsche Mark. The Ausgleichsforderungen accounted for nearly 50 percent of the BdL balance on December $31^{\text {st }} 1950$. Larger liabilities were haircut against newly issued securities, eligible to be discounted at the Federal Reserve Banks (i.e. Landeszentralbanken) of the newly established Central Bank System headed by the BdL. In short, the debt-to-GDP ratio had decreased, since most public debt was converted into Deutsche Mark with an exchange ratio of 1:10. In 1952, Germany joined the Bretton Woods System and pegged its exchange rate to the Dollar. This can be seen as an attempt to return to a rule-based monetary policy. In the two decades following the formation of the Federal Republic of Germany, the general debt-to-GDP ratio fluctuated around 22 percent (Figure 1). However this situation owes far more to the extraordinary economic growth during the "economic miracle" than to fiscal prudence. In fact, the average nominal GDP growth between 1953 and 1973 reached almost 10 percent (Figure 3), while the nominal debt increased from 14.78 to 86.42 billion Marks (Figure 2).

In the late 1960s, a realignment of macroeconomic policy in Germany took place. A new law authorized the government to stabilize economic cycles, using countercyclical fiscal and economic policy (StabG 1967). The implementation of this law is often interpreted as a move towards Keynesian demand side economics. In addition, the constitutional rule restricting public deficits to the volume of 
investment (art. $115 \mathrm{GG}$ ) was amended in $1969 .{ }^{16}$ In the following years both the debt-to-GDP ratio and the amount of nominal debt increased (Figure 1 and 2). While the initial rise in public debt might have resulted from the first serious recession of the post-war era in the 1970s, the German Council of Economic Experts (2005: 478) and the Academic Advisory Board at the Federal Ministry of Economics and Technology (2008), among others, report a bias towards public debt since the constitutional amendment. The debate on the evident increase in public debt marked the starting point of the break-up of the social liberal coalition in 1982 . The following government under Kohl succeeded in consolidating the structural deficit until the eve of German Unification.

However, the costs of the German Unification, combined with the recession of the 1990s resulted in a new increase in public debt (Figure 1 and 2). After the establishment of the European Monetary Union and the implementation of the Stability and Growth Pact (SGP), which limits the amount of national debt and deficits as percentages of GDP to 60 percent and 3 percent, respectively, the German debt-to-GDP ratio has continuously exceeded the Maastricht benchmark of 60 percent. Due to an intervention by Germany and France, the SGP was weakened in 2005. Finally, the Great Recession has led to an increase of the general debt level to over 80 percent or above 2 trillion Euros in 2010 (Figure 1 and 2). An international comparison, however, shows that the fiscal situation is even worse in several other states (see Appendix A.3).

Although Germany has experienced steep increases in its public debt before, both the debt-to-GDP ratio and the nominal amount of debt have never been higher in peacetime than today. The introduction of a constitutional debt brake replacing the former Art. $115 \mathrm{GG}$ is a reaction to this development. Today, the debt rule is in a transition period, giving the state and federal governments time to consolidate their budgets. Starting in 2016, the federal budget has to be close-to-balance after adjusting for cyclical fluctuations. Four years later, the states are no longer permitted to run a structural deficit. Exceptions are narrowly defined and tied to repayment rules, but automatic triggers in the case of contravention are missing. At this stage, several states are struggling to balance their budget, thereby risking an unbalanced budget in 2020 (Deutsche Bundesbank 2011, German Council of Economic Experts 2011). Since legal restrictions to the accumulation of public deficits have been evaded in Germany since the Kaiserreich, and nowadays even on the EU level, the sustainability of public finances is still questionable.

\footnotetext{
${ }^{16}$ Until then article $115 \mathrm{GG}$, adopted from the Weimar constitution, allowed public credit in exceptional situations and for projects leading to a return. Following the financial reform of 1967/69, Art. $115 \mathrm{GG}$ allowed the accruement of debt for public investments and to fight macroeconomic disequilibrium. Further exceptions were allowed for off-budget special funds. The article was amended with the introduction of the debt brake in 2009. For an analysis of this debt brake see Feld and Baskaran (2010).
} 


\subsection{SUMMARY AND FURTHER EVIDENCE}

The anecdotal evidence on the development of public debt in Germany has revealed some key characteristics. First, public debt has particularly increased during economic crises, wars or extraordinary circumstances (i.e., unification). Apart from potentially "good" reasons for fiscal deficits in those times, it is evident that debt has hardly decreased afterwards. Second, constitutional rules restricting the amount of public debt were in place since the formation of the first German nation state. They have obviously been interpreted very loosely. These two characteristics can be explained by Buchanan and Tullock's (1962) theory of the fiscal commons (Schaltegger and Feld 2009a). Third, since 1949 the share of the federal debt level has increased. Fourth, the largest rises in the public debt ratios were accompanied by a loss of independence of the central bank. Fifth, although the Bundesbank gained independence and committed itself to price stability, German fiscal policy was not constrained effectively, as supposed by Sargent and Wallace (1981). ${ }^{17}$

In the current debate on the European debt crisis the call for a growth-oriented policy instead of austerity measures gains popularity. Such a policy is supposed to enable economies to grow out of their debt without the need of (primary) surpluses. As discussed in Section 2, this is only feasible under the assumption that the nominal interest rate remains below the nominal GDP growth rate in the long run. This is not the case. After 1974, economic growth in Germany was lower than the interest rate (Figure 3, bottom). Average economic growth is notably below the average interest rate for this period. In the period before WWI, regarding average values for this period, the interest rate also remained above the rate of economic growth (Figure 3, top). Only in the years of the "economic miracle" the average growth rate of nominal GDP comes close to 10 percent. It therefore exceeds the average interest rate (Figure 3, middle). Given these facts, it is hardly feasible - at least for Germany - to grow out of its debt. The years of the "economic miracle" are the exception rather than the rule.

\footnotetext{
${ }^{17}$ In contrast, the fiscal theory of price level (Leeper 1991, Sims 1994, Woodford 1995) indicates that fiscal policy determines the price level, while monetary policy plays at best an indirect role. Permanent fiscal deficits may induce inflation by their effect on aggregate demand irrespective of monetary policy. In monetary unions - but also in federal states - excessive spending of one state over a long horizon may therefore lead to heterogeneous inflation patterns (Neck and Sturm 2008).
} 

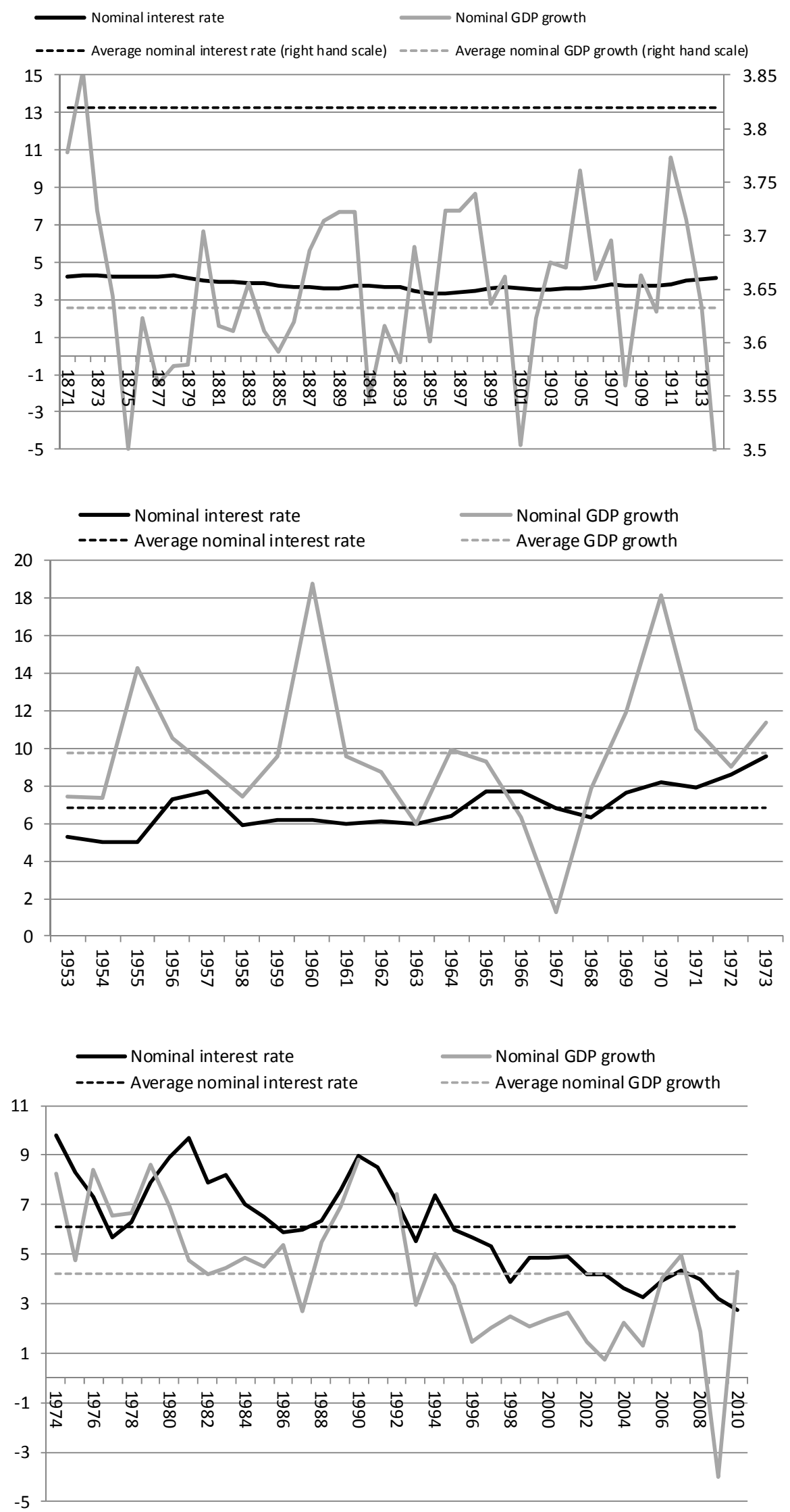


\section{EMPIRICAL ANALYSIS}

In order to test whether the development of public debt described in Section 3 is sustainable, we conduct a time series analysis. Any of the assumptions made and set in the estimations will be discussed subsequently. The four staged approach of this paper is framed by methodological remarks in the introductory (4.1) and in a concluding section (4.6).

\subsection{Data and Empirical Test Strategy}

The empirical analysis is based on annual data covering the period from 1872 to 2010 . The dataset is composed of multiple sets of institutions and sources (see Appendix A.1). The two most commonly stated problems of long time series are inconsistency and timeliness of the data (Reinhart and Rogoff 2009). The available data is indeed not fully consistent, due to varying reporting standards and statistical procedures, causing statistical discrepancies within public spending and income statistics. The consistency of the data is improved, however, when we consider the two sub-periods 1872-1913 and 1950-2010 (see Appendix A.1). In addition, some data are unavailable before 1950: Budget surplus is therefore calculated from the annual differences between revenues and expenditures, until the officially approved data series for annual surpluses started in 1950. Data on primary budget surpluses could not be obtained for this early period.

Table $5 \quad$ Descriptive Statistics

\begin{tabular}{|c|c|c|c|c|c|c|c|c|}
\hline Variable & Unit & Frequency & & Obs** & Mean & Std. Dev. & Min & Max \\
\hline \multirow[t]{3}{*}{ Public Debt } & Share in GDP* & Year & $1872-2010$ & 135 & 0.472 & 0.319 & 0.029 & 2.427 \\
\hline & & & $1872-1913$ & 42 & 0.476 & 0.110 & 0.215 & 0.596 \\
\hline & & & $1950-2010$ & 61 & 0.365 & 0.183 & 0.176 & 0.812 \\
\hline \multirow{3}{*}{$\begin{array}{l}\text { Public Expendi- } \\
\text { tures }\end{array}$} & Share in GDP* & Year & $1872-2010$ & 135 & 0.296 & 0.192 & $0.000^{1}$ & 1.095 \\
\hline & & & $1872-1913$ & 42 & 0.147 & 0.058 & 0.362 & 0.356 \\
\hline & & & $1950-2010$ & 61 & 0.403 & 0.897 & 0.213 & 0.514 \\
\hline \multirow[t]{3}{*}{ Public Revenues } & Share in GDP* & Year & $1872-2010$ & 134 & 0.271 & 0155 & $0.000^{2}$ & 0.609 \\
\hline & & & $1872-1913$ & 42 & 0.143 & 0.071 & 0.013 & 0.356 \\
\hline & & & $1950-2010$ & 61 & 0.383 & 0.081 & 0.216 & 0.481 \\
\hline \multirow[t]{3}{*}{ Budget Surplus } & Share in GDP* & Year & $1872-2010$ & 133 & -0.032 & 0.068 & -0.521 & 0.143 \\
\hline & & & $1872-1913$ & 42 & -0.004 & 0.020 & -0.085 & 0.012 \\
\hline & & & $1950-2010$ & 61 & -0.020 & 0.015 & -0.062 & 0.014 \\
\hline $\begin{array}{l}\text { Primary Budget } \\
\text { Surplus }\end{array}$ & Share in GDP* & Year & $1950-2010$ & 61 & -0.001 & 0.016 & -0.048 & 0.042 \\
\hline CPI Inflation & $\begin{array}{l}\text { Percentage change in } \\
\mathrm{CPI}\end{array}$ & Year & $1950-2010$ & 61 & 0.025 & 0.022 & -0.062 & 0.075 \\
\hline Yield & Percentage points & Year & $1950-2010$ & 61 & 6.305 & 1.720 & 2.743 & 9.8 \\
\hline
\end{tabular}

*See footnotes 10 and 18. **Observations for budget deficit in 1924 and 1949, and for revenues in 1924 are not included. Between 1945 and 1949 data are unavailable. For further details see Appendix A.1. ${ }^{1}$ i.e. $7.85 \mathrm{e}^{-13} ;{ }^{2}$ i.e. $8.75 \mathrm{e}^{-14}$. 


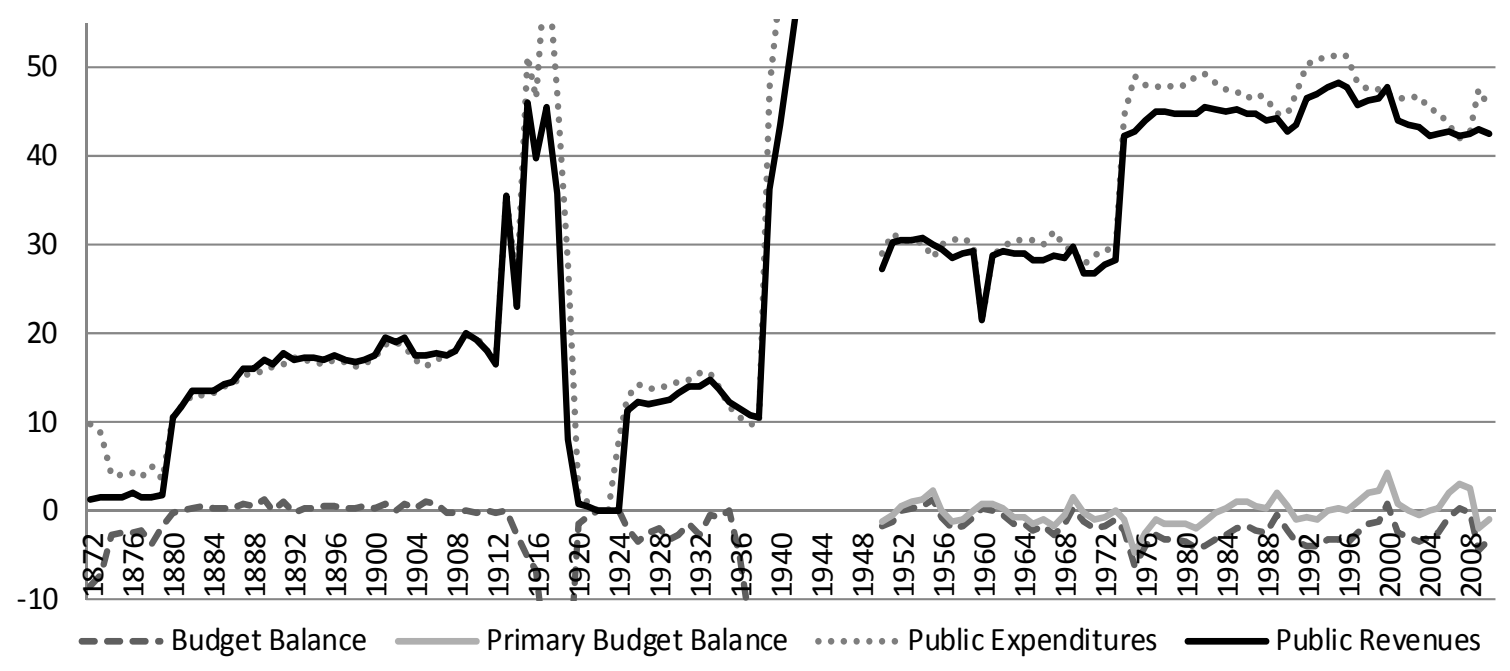

For reasons of clarity, values below -10\% of GDP and above 55\% of GDP are not depicted. Own calculations. Source: Refer to Appendix A.1.

The data are measured in relation to GDP. Drawing on Bohn (2008), such a procedure guarantees a similarly scaled series that offers more credible information, in contrast to raw data or their respective logs. According to Kirchgässner and Prohl (2008) the ratios, as indicated by eq. (6), provide a more natural definition of sustainability. This holds especially with regard to the widely observed phenomenon in time series analysis on debt sustainability of a common stochastic trend in GDP on the one hand and public debt and deficits on the other hand, indicating that "stationarity of the latter two is not necessary for a sustainable fiscal policy" (ibid.: 68). Table 5 provides a summary of the descriptive statistics of all variables used in the empirical analysis. The development of expenditure, revenue and budget surpluses (in \% of GDP) is shown in Figure 4.

In order to test for fiscal sustainability in a more formal manner, we basically follow the approach summarized in section 2 . In a first step, we test whether the transversality condition is met (eq. (1)) by conducting various stationarity tests on public debt, deficits, and, if available, primary surpluses. These tests are also performed with respect to expenditures and revenues. ${ }^{18}$ In order to examine the stationarity properties of the time series, we apply different unit root tests: first, the Augmented Dickey Fuller (ADF) test, determining the number of lags using the Hannan-Quinn criterion; second, the Philipps-Perron (PP) test, selecting the bandwidth automatically in accordance to the NeweyWest procedure using Bartlett kernel; and third the Kwiatkowski-Test (KPSS) with equivalent bandwidth selection procedures (Hamilton 1994, Kirchgässner and Wolters 2006, Kwiatkowski et al. 1992). The tests differ with respect to their null hypotheses: The null hypothesis of the ADF and the PP tests is the existence of a unit root in the time series, whereas the null hypothesis of the KPSS test is trend stationarity of the time series.

\footnotetext{
${ }^{18}$ For a discussion of the limits of stationarity as an indicator for sustainability, see Bohn (2008).
} 
Since unit roots in fiscal data imply that economic shocks have a sustaining effect on the data over time, the identification of a unit root denotes a non-stationary (unsustainable) time series. All tests are applied in levels allowing for a constant and a constant with trend, respectively, and in first differences. In the presence of structural breaks, the power of standard unit root tests is decreased, e.g., the ADF test is biased towards a non-rejection of the null hypothesis. In order to take a possible distortion of structural breaks into account, we follow a twofold approach: First, we conduct the unit root and stationarity tests on the entire sample (1872-2010) and on the two sub-samples (1872-1913 and 1950-2010). Second, we additionally apply a fourth test suggested by Zivot and Andrews (1992). It tests the null hypothesis of a unit root against the break-stationarity alternative using the Akaike Information Criterion (AIC) in order to determine the optimal number of lags. The break date is chosen where the t-statistics from the ADF test is most negative, i.e., the evidence is "least favourable for the unit root null" (Glynn et al. 2007: 68). The Zivot and Andrews test (ZA) is applied in levels allowing for a structural break in the intercept and in the intercept and trend, respectively.

In a second step we perform Johansen cointegration tests to examine whether current debt equals discounted future primary budget surpluses over time (eq. 8). If variables are integrated of order one $[I(1)]$, there may be a linear combination of a lower order of integration, such that a cointegration relation exists. This procedure allows for analysing whether the time series share a common stochastic drift, and to detect the rank of a cointegration matrix ( $r$ ) for a VECM analysis. Hence, a long-term relation, a cointegration vector, and a short term adjustment may be detected once we identify a cointegrated system. Cointegration tests allow for a further analysis of the data beyond standard regressions: If, for example, debt and surpluses are cointegrated, the necessary condition for the sustainability of the intertemporal budget constraint holds (Afonso 2005). Two statistical tests are able to determine the number of cointegration vectors: the Trace test and the Maximum Eigenvalue test. The former tests the null hypothesis that there are at most $r$ cointegration vectors against an unrestricted alternative. The latter tests the null hypothesis that there are $r$ cointegration vectors against the alternative of $r+1$ cointegration vectors.

In a third step, we consider standard VAR tests for those variables that are not I(1). In a VAR the endogenous variables are explained by their own lagged values and the lags of the other variables in the model. In addition, the impact of shocks on the adjustment path is modelled with impulse response functions. This procedure allows for estimating the adjustment processes on increasing public debt ratios, as suggested by Bohn $(1995,1998)$. Furthermore, a VAR can disclose the assumed positive reaction patterns between primary surpluses and debt (Greiner and Kauermann 2007). 
In a fourth step, we test for a simultaneous equilibrium in the dataset and estimate a VECM to further explore the relation between debt, yields and inflation. Impulse response and tests for Granger causality further explore this relation.

\subsection{Results of the UNIt Root Tests}

\subsubsection{2-2010 UNIT RoOTS TESTS RESULTS}

The stationarity tests on the period from 1872-2010 are only indicative, as the whole period is characterized by large scale events and structural breaks. The positively skewed distribution of total debt supports this introductory remark.

Regarding expenditures and revenues, the tests indicate that both are stationary in differences while the results for their levels are ambiguous: Revenues tend to be stationary in levels with trend, as the ADF test statistic allows for rejecting the hypothesis of a unit root on the one percent significance level. In contrast, the KPSS test rejects the null hypothesis of stationarity if we allow for a constant. If we also include a trend in the estimation, we fail to reject the hypothesis of trend stationarity. Hence, revenues seem to be trend stationary in levels if we consider the ADF and KPSS tests. The results of the PP test contradict these findings. To further explore this puzzle, we supplement a ZA unit root test that is sensitive to structural breaks in the intercept and trend. If we allow for a structural break in the intercept, we cannot reject the hypothesis that revenues have a unit root. If we also allow for a structural break in the trend, the hypothesis is retained. Both tests indicate a break point in 1918 and support non-stationarity of revenues.

Expenditures in levels appear to be non-stationary over the whole period and stationary in first differences - which suggests I(1) series - if we consider ADF and PP test results. The hypothesis of stationarity can be rejected by the KPSS tests allowing for a constant. Since KPSS neither rejects stationarity in expenditure levels with trend nor in first differences, the results are, again, puzzling: With a ZA test allowing for a structural break in the intercept, we cannot reject the hypothesis that expenditures have a unit root. Also, the null hypothesis of a unit root with a structural break in both the intercept and trend cannot be rejected. Break points are 1939 with respect to the intercept and 1918 regarding a break in intercept and trend. Comparing expenditure and revenue break points, the ZA results suggest that fiscal policy of the $19^{\text {th }}$ century is significantly different from that of the $20^{\text {th }}$ century. The significant breakpoint in 1939 is due to the sharp increase of expenditure growth to finance WWII.

With respect to surpluses, the ADF and PP tests suggest a unit root in levels with and without a trend. They differ with regard to surpluses and in first differences: The PP test rejects the hypothesis of a 
unit root in first differences, while ADF test does not. Trend stationarity is rejected neither in levels nor in differences by the KPSS test. The ZA test statistic does not allow for a rejection of the hypothesis of a unit root in deficits while choosing 1945 as a break point in the intercept. If we allow for a break in the trend as well, the ZA retains the hypothesis of a unit root with 1955 as a break point the year also well known for its peak growth performance of the German "economic miracle" (Richter 1998: 32). The latter surplus coincides with its maximum value of the second period (1950-2010), as reported in Table 5 at 1.4 percent. Deficits appear to be non-stationary in line with the ADF and the PP tests in levels.

The ADF and PP tests suggest a unit root in levels with and without a trend for public debt. They differ with regard to their test results in first differences: While ADF does not reject the hypothesis of a unit root in first differences, the PP test does so. Trend stationarity is neither rejected in levels nor in differences by the KPSS test. The ZA test statistic does not allow for a rejection of the hypothesis of a unit root in debt while choosing 1945 as a break point in the intercept. If we allow for a break in the trend and intercept, the ZA retains the hypothesis of a unit root with 1956 as a break point. Public debt appears to be non-stationary in support of the ADF and the PP tests in levels.

Given these ambiguous results, we conclude that continuing the analysis with the whole time series is not meaningful. Moreover, the power of standard unit root tests decreases substantially if there are significant structural breaks in the time series. The ZA tests indicate a multiplicity of structural breaks, which reaffirms the results from the anecdotal evidence. Therefore, we divide the sample into two sub-periods as discussed above.

Table 6 Tests for Unit Roots and Stationarity, 1872-2010

\begin{tabular}{|c|c|c|c|c|c|c|c|c|c|c|c|}
\hline \multirow[t]{2}{*}{ Variables } & \multicolumn{2}{|c|}{ ADF test } & \multicolumn{3}{|c|}{ PP test } & \multicolumn{3}{|c|}{ KPSS test } & \multicolumn{3}{|c|}{ ZA test } \\
\hline & Level & $\begin{array}{l}\text { Level } \\
\text { with } \\
\text { trend }\end{array}$ & $\begin{array}{l}\text { First } \\
\text { differences }\end{array}$ & Level & $\begin{array}{l}\text { Level } \\
\text { with } \\
\text { trend }\end{array}$ & $\begin{array}{l}\text { First } \\
\text { differences }\end{array}$ & Level & $\begin{array}{l}\text { Level } \\
\text { with } \\
\text { trend }\end{array}$ & $\begin{array}{l}\text { First } \\
\text { differ- } \\
\text { ences }\end{array}$ & $\begin{array}{l}\text { Inter- } \\
\text { cept }\end{array}$ & $\begin{array}{l}\text { Intercept } \\
\text { and } \\
\text { trend }\end{array}$ \\
\hline $\begin{array}{l}\text { Public Debt } \\
\text { (in \% GDP) }\end{array}$ & -0.126 & -0.100 & -2.011 & 0.174 & 0.212 & $-8.892 * * *$ & 0.096 & 0.079 & 0.075 & $\begin{array}{l}-0.828 \\
(1945)\end{array}$ & $\begin{array}{r}-0.469 \\
(1956)\end{array}$ \\
\hline $\begin{array}{l}\text { Gross Surplus / } \\
\text { Deficit } \\
\text { (in \% GDP) }\end{array}$ & 3.673 & 3.712 & 0.5515 & 3.243 & 3.184 & $-10.455^{* * *}$ & 0.135 & 0.107 & 0.150 & $\begin{array}{r}2.784 \\
(1945)\end{array}$ & $2.283(1955)$ \\
\hline $\begin{array}{l}\text { Expenditures } \\
\text { (in \% GDP) }\end{array}$ & -1.652 & -2.347 & $-5.045 * * *$ & -1.247 & -1.839 & $-10.360^{* * *}$ & $1.062^{* * *}$ & 0.027 & 0.113 & $\begin{array}{l}-2.714 \\
(1939)\end{array}$ & $\begin{array}{r}-2.395 \\
(1918)\end{array}$ \\
\hline $\begin{array}{l}\text { Revenues } \\
\text { (in \% GDP) }\end{array}$ & -2.206 & $-4.369^{* * *}$ & $-6.095 * * *$ & -1.524 & -2.856 & $-11.561^{* * *}$ & $1.170 * * *$ & 0.048 & 0.06 & $\begin{array}{l}-4.304 \\
(1918) \\
\end{array}$ & 4.423 (1918) \\
\hline
\end{tabular}

\subsection{2. $1872-1913$ UNIT ROOTS TESTS RESULTS}

With regard to public debt during the first sub-period of the dataset (1872-1913), the PP unit root tests and the KPSS tests indicate a non-stationary debt time series in levels. The ADF, however, rejects the hypothesis of a unit root in levels, without a trend on a ten percent significance level. If we 
allow for a constant and a trend in the estimation, the ADF retains the null hypothesis. In addition, the ZA rejects neither the hypothesis for a unit root with a structural break in the intercept (1882), nor the hypothesis of a unit root with a structural break in the intercept and trend (1883). Both dates coincide with the start of the depression in Germany (i.e., the Gründerkrach) and the United States. ADF and PP tests on first differences reject unit roots on the one percent level. Also rejecting stationarity in first differences on the ten percent significance level, the KPSS questions whether the debt series is truly I(1).

The annual budget surplus is stationary during this period with regard to the ADF and PP tests. For levels - either with a constant or with a constant and a trend - both unit root tests reject the existence of a unit root at the 1 percent level. This is also reflected by the ZA test that rejects a unit root allowing for a structural break in 1880 for the intercept, but fails to estimate the results allowing for a break in the intercept and the trend as regressors may be perfectly collinear. However, the KPSS test rejects the null hypotheses of trend stationarity in first differences and levels on the five percent level. Hence, the results for budget surplus ratios are not unambiguous.

ADF and PP tests do not reject the hypothesis of a unit root in the data series of expenditures and revenues in levels. The ZA supports these results, reaffirming the structural break in 1880 . The hypothesis of trend stationarity (KPSS) is rejected in levels without trend. Therefore, expenditures and revenues are I(1). The hypothesis of a unit root in differences can be rejected at the 5 percent level according to the ADF and PP test. Similar results are obtained for revenues.

Table $7 \quad$ Tests for Unit Roots and Stationarity, 1872-1913

\begin{tabular}{|c|c|c|c|c|c|c|c|c|c|c|c|}
\hline \multirow[t]{2}{*}{ Variables } & \multicolumn{3}{|l|}{ ADF test } & \multicolumn{3}{|l|}{ PP test } & \multicolumn{3}{|l|}{ KPSS test } & \multicolumn{2}{|l|}{ ZA test } \\
\hline & Level & $\begin{array}{l}\text { Level } \\
\text { with } \\
\text { trend }\end{array}$ & $\begin{array}{l}\text { First } \\
\text { differences }\end{array}$ & Level & $\begin{array}{l}\text { Level } \\
\text { with } \\
\text { trend }\end{array}$ & $\begin{array}{l}\text { First } \\
\text { differences }\end{array}$ & Level & $\begin{array}{l}\text { Level } \\
\text { with } \\
\text { trend }\end{array}$ & $\begin{array}{l}\text { First } \\
\text { differences }\end{array}$ & Intercept & $\begin{array}{l}\text { Intercept } \\
\text { and } \\
\text { trend }\end{array}$ \\
\hline $\begin{array}{l}\text { Public Debt } \\
\text { (in \% GDP) }\end{array}$ & $-2.740 *$ & -1.782 & $-4.186^{* * *}$ & -2.183 & -1.019 & $-4.760^{* * *}$ & $0.603^{* *}$ & $0.191^{* *}$ & $0.352^{*}$ & $\begin{array}{l}-2.780 \\
(1882)\end{array}$ & $\begin{array}{l}-3.571 \\
(1883)\end{array}$ \\
\hline $\begin{array}{l}\text { Gross Surplus / } \\
\text { Deficit } \\
\text { (in \% GDP) }\end{array}$ & $-6.665^{* * *}$ & $-5.861 * * *$ & $-6.484 * * *$ & $-7.477^{* * *}$ & $-5.603^{* * *}$ & $-6.514^{* * *}$ & $0.529^{* *}$ & $0.214^{* *}$ & $0.510^{* *}$ & $\begin{array}{r}-11.820^{* * *} \\
(1880)\end{array}$ & $\begin{array}{r}N A \\
\text { (1880) }\end{array}$ \\
\hline $\begin{array}{l}\text { Expenditures } \\
\text { (in \% GDP) }\end{array}$ & -0.256 & -2.359 & $-3.107^{* *}$ & 0.292 & -2.362 & $-2.978^{* *}$ & $0.697^{* *}$ & $0.121 *$ & 0.231 & $\begin{array}{l}-3.801 \\
(1880)\end{array}$ & $\begin{array}{l}-3.964 \\
(1880)\end{array}$ \\
\hline $\begin{array}{l}\text { Revenues } \\
\text { (in \% GDP) }\end{array}$ & -0.955 & -2.118 & $-3.088^{* *}$ & -0.219 & -2.101 & $-3.244^{* *}$ & $0.682^{* *}$ & $0.172^{* *}$ & 0.150 & $\begin{array}{l}-4.556 \\
(1880)\end{array}$ & $\begin{array}{l}-4.527 \\
(1880) \\
\end{array}$ \\
\hline
\end{tabular}

\subsection{3. $1950-2010$ UnIt RoOts TeSt ResUlts}

For the second sub-period (1950-2010), the officially reported annual budget (gross) surplus and primary surplus are available. ${ }^{19}$ Public debt is non-stationary in levels as ADF and PP indicate. This is

\footnotetext{
${ }^{19}$ We thank Mrs. Ilsemarie Lenz at the Federal Statistical Office of Germany (Statistisches Bundesamt), who has provided us all relevant missing data for interest payments during the years 1950-1962. We could not have conducted this analysis without her help and her instant replies when data related problems occurred.
} 
validated by the rejection of the hypothesis of trend stationarity in debt levels by the KPSS test. Unit roots can be rejected in first differences on the five percent significance level. In contrast to this finding, stationarity of the debt ratio in first differences can be rejected on the 5 percent level. Allowing for a trend in the difference estimation solves this ambiguity by not rejecting stationarity $\left(0.036 \mathrm{t}_{\mathrm{i}}<\right.$ $\left.0.119 t_{\text {crit.10\% }}\right)$. A linear trend in differences corresponds with a deterministic trend in levels. An economic explanation for this empirical result could be found in the ever increasing sovereign debt ratios since 1950. Structural breaks are found in 1968, allowing for a break in the intercept and 1972, allowing for an additional break in the trend. Both dates coincide with the paradigm shift in post-war German fiscal policy. As unit roots cannot be rejected in levels, the ZA test supports the empirical evidence that public debt is integrated of order one.

Gross and primary deficits are, in contrast, not I(1). ADF and PP tests conjointly reject a unit root in levels and first differences. The KPSS tests confirm these results for stationarity of both time series in first differences. The hypothesis of stationary primary deficits in levels without trend cannot be rejected, in contrast to gross surplus. Considering a trend in both tests allows for the rejection of the hypothesis of trend stationary deficits in both cases. If we allow for a structural break in the regression, however, we can reject the hypothesis of a unit root in gross and primary deficits at least on the five percent level. The break is significant in 1997 for gross deficits and in 1985 for primary deficits, and for 1974 and 1984, respectively, if we also allow for a trend in the estimation. Supporting the results of the ADF and PP test in levels, the ZA test provides further evidence that we cannot treat the series as I(1).

Table 8 Tests for Unit Roots and Stationarity 1950-2010

\begin{tabular}{|c|c|c|c|c|c|c|c|c|c|c|c|}
\hline \multirow[t]{2}{*}{ Variables } & \multicolumn{3}{|l|}{ ADF test } & \multicolumn{3}{|l|}{ PP test } & \multicolumn{3}{|l|}{ KPSS test } & \multicolumn{2}{|l|}{ ZA test } \\
\hline & Level & $\begin{array}{l}\text { Level with } \\
\text { trend }\end{array}$ & $\begin{array}{l}\text { First } \\
\text { differences }\end{array}$ & Level & $\begin{array}{l}\text { Level with } \\
\text { trend }\end{array}$ & $\begin{array}{l}\text { First } \\
\text { differences }\end{array}$ & Level & $\begin{array}{l}\text { Level } \\
\text { with trend }\end{array}$ & $\begin{array}{l}\text { First } \\
\text { differences }\end{array}$ & Intercept & $\begin{array}{l}\text { Intercept and } \\
\text { trend }\end{array}$ \\
\hline $\begin{array}{l}\text { Public Debt } \\
\text { (in \%GDP) }\end{array}$ & 1.529 & -1.168 & $-3.403^{* *}$ & 1.678 & -1.133 & $-3.573^{* *}$ & $0.911^{* * *}$ & $0.225^{* * *}$ & $0.717^{* *}$ & $\begin{array}{l}-2.315 \\
(1968)\end{array}$ & $-4.270(1972)$ \\
\hline $\begin{array}{l}\text { Gross Surplus / } \\
\text { Deficit } \\
\text { (in \% GDP) }\end{array}$ & $-3.558 * * *$ & $-3.943 * *$ & $-7.161^{* * *}$ & $-3.426^{* *}$ & $-3.892^{* *}$ & $-13.434^{* * *}$ & $0.485^{* *}$ & $0.191^{* *}$ & 0.247 & $\begin{array}{r}-5.595 * * * \\
(1997)\end{array}$ & $\begin{array}{r}-6.449 * * * \\
(1975)\end{array}$ \\
\hline $\begin{array}{l}\text { Primary Deficit } \\
\text { (in \% GDP) }\end{array}$ & $-3.766^{* * *}$ & $-4.211^{* * *}$ & $-6.767^{* * *}$ & $-3.615^{* * *}$ & $-3.501^{* *}$ & $-9.494 * * *$ & 0.213 & $0.135^{*}$ & 0.233 & $\begin{array}{r}-5.207^{* *} \\
(1985)\end{array}$ & $\begin{array}{r}-5.408^{* *} \\
(1984)\end{array}$ \\
\hline $\begin{array}{l}\text { Expenditures } \\
\text { (in \% GDP) }\end{array}$ & -1.481 & -1.792 & $-7.427^{* * *}$ & -1.500 & -1.863 & $-7.370^{* * *}$ & $0.729 * *$ & $0.166^{* *}$ & 0.096 & $\begin{array}{r}-8.927 * * * \\
(1974)\end{array}$ & $\begin{array}{r}-8.850 * * * \\
(1974)\end{array}$ \\
\hline $\begin{array}{l}\text { Revenue } \\
\text { (in \% GDP) } \\
\end{array}$ & -1.545 & -1.745 & $-8.688^{* * *}$ & -1.512 & -1.806 & $-8.622 * * *$ & $0.745^{* * *}$ & $0.143^{*}$ & 0.124 & $\begin{array}{r}-9.380 * * * \\
(1974) \\
\end{array}$ & $\begin{array}{r}-9.309 * * * \\
(1974) \\
\end{array}$ \\
\hline \multicolumn{12}{|c|}{$\begin{array}{l}\text { Note: The values are the estimated t-statistics. '***', '**' } \text { or }^{\prime} *^{\prime} \text { indicate that the corresponding null hypothesis of a unit root can be re } \\
\text { jected (KPSS: null hypothesis: no unit root) at the } 1,5 \text {, or } 10 \text { percent level, respectively. '(yyyy)' indicates the year for the ZA break point } \\
\text { For further information please consult the Note of Table } 6 \text { and the Eviews workfile, respectively. }\end{array}$} \\
\hline \multicolumn{12}{|c|}{ The ADF and PP tests in levels reflect the results from the first period, with regard to governmen } \\
\hline \multicolumn{12}{|c|}{ expenditures and revenues. The KPSS null hypothesis of trend stationarity can be rejected in levels, } \\
\hline \multicolumn{12}{|c|}{ allowing for a constant with or without a trend at least at the 10 percent level, but must be retained } \\
\hline \multicolumn{12}{|c|}{ in first differences. The two variables therefore appear to be I(1). Following the ZA test results, reve- } \\
\hline
\end{tabular}


cept and trend, while choosing 1974 as a break point. The frequent appearance of structural breaks in the 1970s underpins the fiscal implications of the reforms during this period, as mentioned in the anecdotal analysis.

Given the results of the unit root and trend stationarity tests of the period from 1950-2010, we conclude that the necessary condition for the sustainability of the intertemporal budget constraint is not met, as the transversality condition does not hold due to the non-stationarity of public debt. The determinants of public debt of this period will be further discussed in Section 4.5. In addition, we find evidence for a stationary deficit variable (see Section 4.4) and - as far as unit root and stationarity tests are concerned - evidence that revenues and expenditures are I(1), which will be further explored in Section 4.3 comparing both periods.

\subsection{SUStAinABiLITY TEST Of EXPENDITURES AND REVENUES}

In order to determine the number of cointegrating vectors in the system, we perform Johansen cointegration tests for the time periods of 1872-1913 and 1950-2010. The lag lengths are selected from two VAR models. The first model (1872-1913) retrieves the following lag lengths: 2 Akaike Information Criterion (AIC); 1 Schwarz Criterion (SC); 2 Hannan Quinn Criterion (HQ). The second model (1950-2010) retrieves the same lag structure [2 AIC ; 1 SC , 2 HQ]. Subtracting one lag length for the application of the Johansen cointegration test, which is tested in first differences, we obtain the test results as reported in Table $9 a$ if we assume a stochastic trend in the two periods, and the test results as reported in Table $9 \mathrm{~b}$ if we assume a trend in the series as well as in the cointegration relation.

Table 9a Johansen Test on expenditures and revenues for both sub-periods with intercept in cointegration

\begin{tabular}{|c|c|c|c|c|c|}
\hline & Null Hypothesis & Eigenvalue & & Trace Statistic & $5 \%$ critical value \\
\hline \multirow[t]{5}{*}{$1872-1913$} & None & & 0.469 & $26.370 * *$ & 15.495 \\
\hline & At most1 & & 0.010 & 0.413 & 3.843 \\
\hline & & \multicolumn{3}{|r|}{ Max Eigenvalue } & \\
\hline & & 0 & 0.469 & $25.956^{* *}$ & 14.265 \\
\hline & & 1 & 0.010 & 0.414 & 3.843 \\
\hline \multirow[t]{6}{*}{$1950-2010$} & Null Hypothesis & Eigenvalue & & Trace Statistic & $5 \%$ critical value \\
\hline & None & & 0.273 & $21.343^{* *}$ & 15.495 \\
\hline & At most 1 & & 0.036 & 2.222 & 3.843 \\
\hline & & \multicolumn{3}{|r|}{ Max Eigenvalue } & \\
\hline & & 0 & 0.273 & $19.121^{* *}$ & 14.265 \\
\hline & & 1 & 0.036 & 2.222 & 3.842 \\
\hline
\end{tabular}

Note: ${ }^{* * \prime}$ indicates that the null hypothesis of no cointegration can be rejected on the 5 percent level. The null hypothesis is the hypothesized number of cointegration relations, i.e. the rank of the matrix ( $r$ ). The number of cointegration relations (No. of CIR) is smaller than 1 , i.e., "None", following Trace test's null hypothesis. If the statistic is higher than the critical value, the null hypothesis is rejected. Hence, the null of "None" is rejected as shown above. The hypothesis of "At most 1" cannot be rejected by the Trace test. The Eigenvalue test has a slightly different null hypothesis: Null is "No. of CIR $=r$ " which is zero " 0 " which is rejected at the 5 percent significance level. The critical values for both tests are derived from the Trace and Maximum Eigenvalue of the stochastic matrix. 
With regard to Table 9a, we can reject the hypothesis of no cointegration at the 5 percent significance level for revenues and expenditures in both periods: Trace and Maximum Eigenvalue tests indicate one cointegration vector at the same significance level for the rank of one. Table $9 \mathrm{~b}$ shows the values for the Johansen test assuming a trend in the data series and allowing for an intercept and trend in the cointegration relation. We reject the hypothesis of no cointegration at the 5 percent significance level for revenues and expenditures in the first period. Trace and Maximum Eigenvalue tests differ with regard to their results for the second period: The Trace test statistic does not allow for rejecting the hypothesis of no cointegration in contrast to the Maximum Eigenvalue test. Cheung and Lai (1995) show that the Trace test is more robust than the Maximum Eigenvalue test with regard to skewness and excess kurtosis of residuals of the estimation. Based on this, we reject a cointegration in the second period (1950-2010) if we assume a trend in the cointegration relation. Nevertheless, we will report a test on the above mentioned sustainability vector of $[1,-1]$ to double-check Cheung and Lai (1995).

Table 9b Johansen Test on expenditures and revenues for both sub-periods with intercept and trend in cointegration

\begin{tabular}{|c|c|c|c|c|c|}
\hline & Null Hypothesis & Eigenvalue & & Trace Statistic & $5 \%$ critical value \\
\hline \multirow[t]{5}{*}{$1872-1913$} & None & & 0.500 & $34.183^{* *}$ & 25.872 \\
\hline & At most 1 & & 0.130 & 5.7512 & 12.518 \\
\hline & \multicolumn{5}{|c|}{ Max Eigenvalue } \\
\hline & 0 & & 0.500 & $28.432^{* *}$ & 19.387 \\
\hline & 1 & & 0.130 & 5.751 & 12.518 \\
\hline \multirow[t]{6}{*}{$1950-2010$} & Null Hypothesis & Eigenvalue & & Trace Statistic & $5 \%$ critical value \\
\hline & None & & 0.278 & 22.985 & 25.872 \\
\hline & At most 1 & & 0.056 & 3.345 & 12.518 \\
\hline & \multicolumn{5}{|c|}{ Max Eigenvalue } \\
\hline & & 0 & 0.278 & $19.538^{* *}$ & 19.387 \\
\hline & & 1 & 0.056 & 3.446 & 12.518 \\
\hline
\end{tabular}

Note: ${ }^{* *}{ }^{\prime}$ indicates that the null hypothesis of no cointegration can be rejected at the 5 percent level. The null hypothesis is the hypothesized number of cointegration equations, i.e., the rank of the matrix. (See also: Note Table 9a)

In line with the second step of our procedure as outlined above, we now estimate VECM models for the two sub-periods and both trend assumptions, respectively. Our main objective is to check whether the hypothesis that a one percentage point increase in revenues leads to a one percentage point increase in expenditures (and vice versa) can be rejected within the four systems: Econometrically, we analyse whether the cointegrating vector of rank 1 is $[1,-1]$. This vector is associated with fiscal sustainability of expenditures and revenues (Afonso 2005). Afonso (2005) assumes that sustainability in fiscal policy is given, if the time series of expenditures and revenues are cointegrated and if the hypothesis of a "normality vector" of $[1,-1]$ holds. Vice versa, fiscal unsustainability is the case if a cointegration relation $[1,-1]$ can be rejected. Due to this, the vector, and its corresponding 
Chi-Square test, is used in recent contributions to detect whether revenues and expenditures have followed a sustainable path (e.g., Kirchgässner and Prohl 2008).

1872-1913 Results

The 1872-1913 VAR suggests a lag length of zero for the VECM of the cointegrated time series. Assuming a deterministic trend in the dataset and allowing for a constant in the cointegration relation provides the following system:

Table $10 \quad$ Test for sustainability vector $[1,-1]$ without trend in cointegration relation between expenditures and revenues, 1872-1913

\begin{tabular}{lc}
\hline $\begin{array}{l}\text { Restrictions identify all cointegrating vectors } \\
\text { LR test for binding restrictions (rank = 1) }\end{array}$ \\
\hline Chi-Square(1) & 2.168 \\
\hline Probability & 0.141 \\
Revenues(-1) & 1.000 \\
Expenditures(-1) & -1.000 \\
Constant & 0.004 \\
\hline Note: The null hypothesis of the Chi-Square $[1,-1]$ test is that a one percentage point increase in revenues leads to a one percentage point
\end{tabular}
increase in expenditures.

The null hypothesis that the cointegrating vector is $[1,-1]$ cannot be rejected by the Chi-Square on the underlying system (Table 10): The p-value of the Chi-Square statistic is higher than the five percent critical value (0.141). This is evidence that revenues and expenditures are cointegrated with a sustainability vector. Given the test result, fiscal policy has been sustainable over the period from 1872-1913, assuming a constant GDP growth rate of and allowing for a Wagnerian trend in the dataset of fiscal policy (see also Feld and Schaltegger 2010).

Table 11 Test for sustainability vector $[1,-1]$ with trend in cointegration relation between expenditures and revenues, 1872-1913

\begin{tabular}{lc}
\hline Chi-Square(1) & $4.546^{* *}$ \\
\hline Probability & 0.033 \\
\hline Revenues(-1) & 1.000 \\
\hline Expenditures(-1) & -1.000 \\
@TREND(71) & -0.0001 \\
\hline C & $(0.0003)$ \\
\hline Note: '**' indicates that the hypothesis of the Chi-Square test $[1,-1]$ can be rejected on the 5 percent significance level.
\end{tabular}

We repeat the Chi-Square test, allowing for a trend in the cointegration relation (Table 11). The Johansen procedure allows for an identical variation, due to the Trace and Eigenvalue test results that conjointly indicate one cointegration equation, assuming a trend in the dataset as well as in the cointegration equation (Table 9b). As shown in Table 11, the hypothesis of a cointegrating vector of $[1,-1]$ 
is rejected at least on the five percent significance level with a Chi-Square value of 4.546. Sustainability of fiscal policy could thus be doubted if we allow for a trend in the cointegration relation.

\section{0-2010 Results}

Applying the same restrictions on the VECM for the second period reveals a different result compared to the fiscal policy in the German Empire before WWI.

Table 12 Test for sustainability vector [1,-1] without trend in cointegration relation between expenditures and revenues, 1950-2010

\begin{tabular}{lc}
\hline Chi-Square(1) & $7.128 * * *$ \\
Probability & 0.008 \\
Revenues (-1) & 1.000 \\
Expenditures(-1) & -1.000 \\
Constant & 0.019448 \\
\hline Note: ${ }^{* * * *^{\prime}}$ indicates that the hypothesis of the Chi-Square test [1,-1] can be rejected on the 1 percent significance level.
\end{tabular}

The null hypothesis of a cointegrating vector of $[1,-1]$ is rejected on the 5 percent significance level (Table 12). In contrast to the first period, the fiscal sustainability vector does not hold for the period between 1950 and 2010. A variation of the test with regard to a trend in the cointegration equation is supplemented (Table 13): Note that the trend is significant on the 10 percent level. However, the negative coefficient is very small, at 4 basis points.

We conclude that revenues and expenditures have not followed a sustainable path since 1950 . If we allow for trends in the cointegration, neither period is associated with fiscal sustainability in revenues and expenditures. It therefore appears that unsustainability is robust even considering a GDP trend over the long run. If the series are I(1), cointegrated and if a corresponding VECM does not reject the vector $[1,-1]$, a trend in the cointegration equation should be minded - particularly for long time series. If the hypothesis of a normality vector is still rejected, one can assume that revenues and expenditures are unsustainable.

Table 13 Test for sustainability vector $[1,-1]$ with trend in cointegration relation between expenditures and revenues, 1950-2010

\begin{tabular}{ll}
\hline Chi-Square(1) & $4.566^{* *}$ \\
\hline Probability & 0.033 \\
\hline Revenues(-1) & 1.000 \\
\hline Expenditures(-1) & -1.000 \\
& -0.0004 \\
@TREND(71) & $10.0002)$ \\
\hline C & {$[1.868]$} \\
\hline Note: ${ }^{* *^{\prime}}$ indicates that the hypothesis of the Chi-Square test can $[1,-1]$ be rejected on the 5 percent significance level.
\end{tabular}




\subsection{Multivariate Analysis of Budget Deficits and Debt Ratios}

The third step of our procedure is to estimate a VAR to further explore the determinants of gross and primary budget deficits that have been stationary in levels over each sub-period. This allows for a rediscussion of the existing empirical results on German fiscal policy and general reaction patterns in fiscal policy with regard to the primary surplus. Bohn $(1998,2008)$ finds evidence for a positive conditional response of primary surpluses to increases in the debt ratio. A positive and significant reaction coefficient is commonly viewed as a condition for fiscal sustainability, following Bohn's Model-Based Sustainability (MBS) test. Even if the response is non-linear or time varying, a positive fiscal reaction to increasing public debt ratios by increasing the surplus is considered to be a necessary condition.

Mendoza and Ostry (2008) find such a reaction pattern for Germany and other countries during 1990-2005. Greiner and Kauermann (2008) find evidence for a positive reaction coefficient, however, "with a declining tendency" in a dataset from 1960 to 2003 (Greiner and Kauermann 2008: 1152). Fincke and Greiner (2009) repeat the analysis with a dataset from 1971 to 2006 that is later (2011) expanded to a period from 1950 to 2007. Their results reaffirm the positive reaction function on the one hand and the conclusion of public debt sustainability on the other hand (Fincke and Greiner 2011: 211). However they point out, that a rising debt ratio is not "compatible with sustainability in the long-run", admitting that German debt may "exceed a certain critical value beyond which sustainability is excluded" (ibid.). Due to these results, we ask whether there is such a positive and significant coefficient for the debt-to-GDP ratio in our data set. We are furthermore interested in the reaction of fiscal policy to changes in interest rates and inflation. Thus, we conduct this empirical analysis with two VARs, one for the primary surpluses, the other for gross surpluses.

At first, we retrieve the lag lengths for the two VARs. For the primary surpluses VAR we detect the following lags: AIC: $2 \mathrm{SC}: 1 \mathrm{HQ}: 1$. These lengths coincide with the results for gross surpluses. Both VARs should thus be tested with one and two lags, which is also meaningful from the perspective of political economy: Fiscal path dependency on the one hand and the observation that democracies plan each fiscal year in advance on the other hand. Our objective is to analyse whether the lagged values have a significant effect on the two budget ratios. Annual yields and CPI inflation are included as controls. The results of the VARs with two lags are shown in Table 14 (and in Table A.2.1 (one lag) in the Online Appendix). 
Table 14 Results from VAR estimates of budget surpluses, 1950-2010

\begin{tabular}{|c|c|}
\hline Variables & $\begin{array}{l}\text { Primary Surplus } \\
\text { in } \% \text { of GDP }\end{array}$ \\
\hline \multirow[t]{3}{*}{ Primary Surplus Ratio t - 1} & 0.478 \\
\hline & (0.155) \\
\hline & [ 3.11] \\
\hline \multirow[t]{3}{*}{ Primary Surplus Ratio t - 2} & -0.506 \\
\hline & $(0.140)$ \\
\hline & {$[-3.60]$} \\
\hline \multirow[t]{3}{*}{ Yield t - 1} & -0.001 \\
\hline & (0.199) \\
\hline & {$[-0.003]$} \\
\hline \multirow[t]{3}{*}{ Yield t - 2} & -0.042 \\
\hline & $(0.210)$ \\
\hline & {$[-0.20]$} \\
\hline \multirow[t]{3}{*}{ Debt Ratio t - 1} & -0.031 \\
\hline & $(0.106)$ \\
\hline & {$[-0.29]$} \\
\hline \multirow[t]{3}{*}{ Debt Ratio t - 2} & 0.049 \\
\hline & $(0.111)$ \\
\hline & [ 0.44] \\
\hline \multirow[t]{3}{*}{ CPI t - 1} & -0.331 \\
\hline & $(0.122)$ \\
\hline & {$[-2.70]$} \\
\hline \multirow[t]{3}{*}{ CPI t - 2} & -0.174 \\
\hline & $(0.094)$ \\
\hline & {$[-1.85]$} \\
\hline \multirow[t]{3}{*}{ Constant } & 0.005 \\
\hline & $(0.011)$ \\
\hline & [ 0.382$]$ \\
\hline R-squared & 0.548 \\
\hline Adj. R-squared & 0.476 \\
\hline Sum sq. resids & 0.007 \\
\hline S.E. equation & 0.012 \\
\hline F-statistic & 7.586 \\
\hline Log likelihood & 182.852 \\
\hline AIC & -5.894 \\
\hline SC & -5.577 \\
\hline Mean dependent & -0.0004 \\
\hline S.D. dependent & 0.016 \\
\hline
\end{tabular}

\begin{tabular}{|c|c|}
\hline Variables & $\begin{array}{l}\text { Gross Surplus in } \% \text { of } \\
\text { GDP }\end{array}$ \\
\hline \multirow[t]{3}{*}{ Surplus Ratio t - 1} & 0.384 \\
\hline & (0.161) \\
\hline & [ 2.39] \\
\hline \multirow[t]{3}{*}{ Surplus Ratio t - 2} & -0.280 \\
\hline & $(0.118)$ \\
\hline & {$[-2.38]$} \\
\hline \multirow[t]{3}{*}{ Yield t - 1} & -0.242 \\
\hline & (0.169) \\
\hline & {$[-1.43]$} \\
\hline \multirow[t]{3}{*}{ Yield t - 2} & -0.146 \\
\hline & $(0.190)$ \\
\hline & [ -0.77] \\
\hline \multirow[t]{3}{*}{ Debt Ratio t - 1} & -0.073 \\
\hline & $(0.093)$ \\
\hline & {$[-0.78]$} \\
\hline \multirow[t]{3}{*}{ Debt Ratio t - 2} & 0.030 \\
\hline & $(0.092)$ \\
\hline & [ 0.322] \\
\hline \multirow[t]{3}{*}{ CPI t - 1} & -0.205 \\
\hline & (0.101) \\
\hline & {$[-2.04]$} \\
\hline \multirow[t]{3}{*}{ CPI t -2} & -0.116 \\
\hline & $(0.078)$ \\
\hline & {$[-1.45]$} \\
\hline \multirow[t]{3}{*}{ Constant } & 0.032 \\
\hline & $(0.01)$ \\
\hline & {$[2.83]$} \\
\hline R-squared & 0.631 \\
\hline Adj. R-squared & 0.572 \\
\hline Sum sq. resids & 0.005 \\
\hline S.E. equation & 0.010 \\
\hline F-statistic & 10.697 \\
\hline Log likelihood & 192.1992 \\
\hline AIC & -6.210 \\
\hline SC & -5.893 \\
\hline Mean dependent & -0.019 \\
\hline S.D. dependent & 0.015 \\
\hline
\end{tabular}

Note: The numbers in parentheses indicate the standard error. The numbers in square brackets are absolute values of the estimated t-statistics.

With regard to Table 14, lagged debt ratios and the cost of debt (yields) are not significant for primary surpluses, while both, own lagged values and the lagged CPI, are significant at least at the five percent level. These results are supported by the gross surplus VAR. A constant is, however, only significant in the gross surplus VAR at the five percent level. Contrary to the findings mentioned 
above, both VARs do neither indicate a positive nor a significant coefficient for total debt. The gross surplus VAR has normally distributed residuals: We cannot reject the hypothesis of normality with a Jarque-Bera test value of 8.34 . The residuals of the primary surplus VAR are however not normally distributed: With a Jarque-Bera of 65.10 we can reject the hypothesis that the residuals are multivariate normal. Therefore, the following analysis focuses on the gross surplus VAR only.

\section{Table 15 VAR Granger Causality and Block Exogeneity Wald Test Results for budget surpluses and yields,} 1950-2010

Dependent variable: Gross Surplus

\begin{tabular}{llll}
\hline \hline Excluded & Chi-sq & df Prob. \\
\hline \hline Yield & 5.993799 & 2 & 0.0499 \\
Debt Ratio & 13.86591 & 2 & 0.0010 \\
CPI & 6.442257 & 2 & 0.0399 \\
\hline \hline All & & & \\
\hline \hline
\end{tabular}

Dependent variable: Debt Ratio

\begin{tabular}{llll}
\hline \hline Excluded & Chi-sq & dfProb. \\
\hline \hline Gross Surplus & 3.856132 & 2 & 0.1454 \\
Yield & 1.150911 & 2 & 0.5624 \\
CPI & 6.018748 & 2 & 0.0493 \\
\hline \hline All & 10.96006 & 6 & 0.0896
\end{tabular}

Dependent variable: Yield

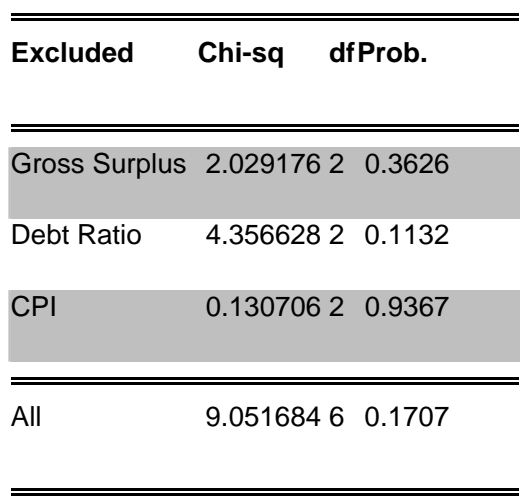

Dependent variable: CPI

Excluded Chi-sq dfProb.

\begin{tabular}{lll}
\hline \hline Gross Surplus & 0.3566982 & 0.8367 \\
Yield & 15.613142 & 0.0004 \\
Debt Ratio & 0.3386732 & 0.8442 \\
\hline \hline All & 18.738966 & 0.0046 \\
\hline \hline
\end{tabular}

The next step is to continue the analysis with a VAR Granger causality and Block Exogeneity Wald Tests, which investigate and examine the causal relation of the variables in the model. This is important because the test results inform about the direction of causality among the variables, which can be unidirectional, bi-directional or neutral. The results are reported in Table 15. The Chi-Square statistic of 13.866 for debt with reference to gross surplus tests the hypothesis that lagged coefficients of debt in the regression equation of gross surplus are equal to zero. In accordance, the lagged coefficients of yields and CPI as well as the block of all coefficients are equal to zero. This is empirical evidence that gross surplus is influenced by yields, debt and CPI and by all three variables together. Debt, yields and CPI are Granger causal at least at the 5 percent significance levels. They are con- 
jointly Granger causal for surplus at the 1 percent significance level. Block exogeneity is, however, accepted when yields and debt are taken as dependent variables. Debt and yield are therefore not jointly influenced by the other variables. The hypothesis of Block exogeneity is rejected for CPI. Surplus and yields are not Granger causal. Yields and surplus are unidirectional. Yields are Granger causal for surplus, but not vice versa. This is exactly the same with debt and CPI. Debt and CPI are Granger causal for surplus, but not vice versa.

Figure 5 Impulse Response Tests for the Gross Surplus VAR, 1950-2010
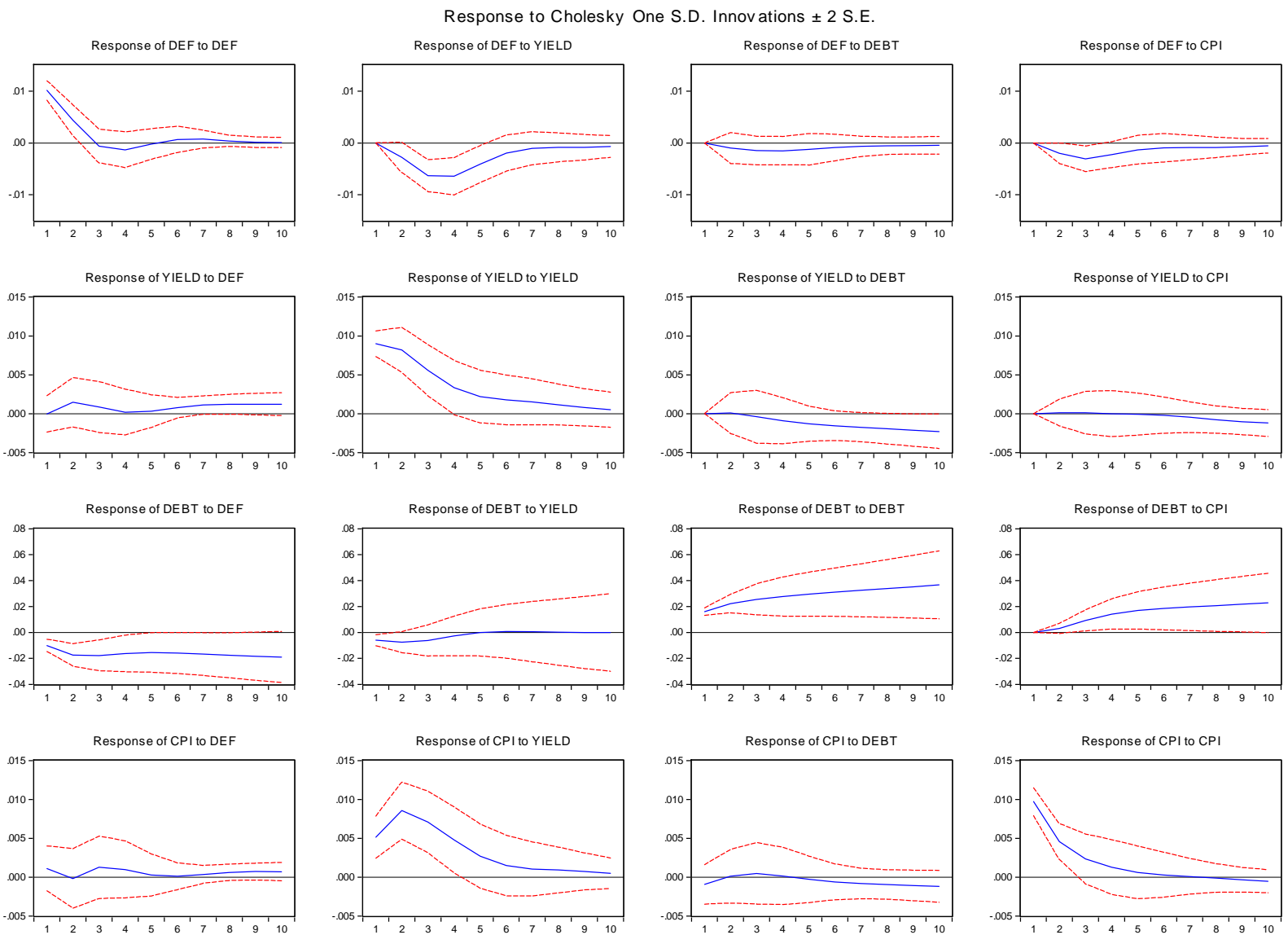

The most common way to analyse VAR models is the use of impulse response functions. An impulse response analysis examines the effect of current and past shocks on the time series. We consider shocks to each residual in the system and the effects on all variables of the VAR. The impulse responses are shown in Figure 5 as solid lines. The dotted lines define confidence intervals of two standard deviations. If these confidence intervals include zero, it can be concluded that the impulse response is not significantly different from zero.

The first column of the graph shows the effect of a one standard deviation shock to the gross surplus residuals. The first of these four graphs illustrates the effect of the shock of gross surplus on itself. It rapidly disappears with a sustaining positive effect at the first lag and a small negative impact on its second lagged value as shown above in the VAR. The second, third and fourth graph of this first col- 
umn show the effects of the shock on yields, debt ratios and CPI, respectively. The only evidence is that an unforeseen standard deviation increase in primary surpluses decreases CPI. With regard to the confidence intervals, CPI (yields) include zero, i.e., the impulse response is not significantly different from zero. Taking into account the complexity of determinants of CPI (and yields) this is not surprising. The confidence intervals of gross surplus and public debt do not include zero until the second and fourth year respectively. Though Granger causing surplus, debt is neither positive nor significant which is why we cast doubt on the empirical findings of the above mentioned papers. Again, primary surplus did not even pass the normality test, which is why we discarded a further analysis.

\subsection{Vector Error Correction Model for Government Debt ratios}

The fourth step is to identify a simultaneous equilibrium in the dataset with respect to government debt. Since we have not discussed debt ratios so far, we estimate a VECM to further explore the relation between yields and debt. The unit root and stationarity tests have shown that debt is I(1). A VAR is tested to retrieve the lag length for the procedure on $\mathrm{CPI}$, yields and the debt ratio and throughout the procedure. The cointegration test indicates one cointegration equation at the five percent level as reported in Table 16.

Table $16 \quad$ Johansen Test on yields and debt

\begin{tabular}{|c|c|c|c|c|}
\hline & Null Hypothesis & Eigenvalue & Trace Statistic & $5 \%$ critical value \\
\hline \multirow[t]{5}{*}{$1950-2010$} & None & 0.362 & $39.710 * *$ & 29.797 \\
\hline & At most 1 & 0.196 & 13.235 & 15.495 \\
\hline & \multicolumn{4}{|c|}{ Max Eigen Value } \\
\hline & None & 0.362 & $26.476 * *$ & 21.132 \\
\hline & 1 & 0.196 & 12.893 & 14.265 \\
\hline
\end{tabular}

Note: ${ }^{* * \prime}$ indicates that the null hypothesis of no cointegration can be rejected at the 5 percent level. See also: Notes of Table $9 a$.

Allowing for a deterministic linear trend in the dataset, and a constant in the cointegration equation, the VECM results are shown in the eq. (9) to (11) below. The resulting residuals are tested for normality: The null hypothesis of normal distribution of the residuals cannot be rejected (the JarqueBera test statistic is 9.067). According to the KPSS test, the cointegration vector is stationary $(0.112$ in levels with a constant and 0.100 with trend). The following system provides robust evidence on the long and short run relation between the debt-to-GDP ratio, government bond yields and the CPI. While the long run relation is significant for yields and the debt-to-GDP ratio, it is not for the CPI. Looking at the debt equation (10), all three lagged coefficients are significant in the short run. Block exogeneity can be rejected for the debt equation at a significance level of 1 percent. CPI Granger causes debt but not vice versa. Similarly, yields Granger cause debt at a 1 percent significance level but not vice versa. This is evidence for a unidirectional relation. Block exogeneity cannot be rejected for equations (9) and (11). Yields and CPI are not jointly influenced by the other variables. 


$$
\begin{aligned}
& \mathrm{D}(\mathrm{YIELD})=-0.445 *(\mathrm{YIELD}(-1)+0.004 * \text { DEBTRATIO(-1) }-0.001 * \text { CPI2005 }(-1)-0.080) \\
& \text { [-3.040] [5.479] [-4.172] } \\
& +0.260 * \mathrm{D}(\mathrm{YIELD}(-1))+9.966 \mathrm{e}-05 * \mathrm{D}(\mathrm{DEBTRATIO}(-1))-0.001 * \mathrm{D}(\mathrm{CPI} 2005(-1))+0.002 \\
& {[1.706] \quad[0.161] \quad[-1.118] \quad[0.727]} \\
& \text { D }(\text { DEBTRATIO })=-83.946 *(\text { YIELD }(-1)+0.004 * \text { DEBTRATIO }(-1)-0.001 * \text { CPI2005 }(-1)-0.080) \\
& {[-2.582] \quad[5.479] \quad[-4.172]} \\
& +56.140 * \mathrm{D}(\mathrm{YIELD}(-1))+0.641 * \mathrm{D}(\mathrm{DEBTRATIO}(-1))+0.905 * \mathrm{D}(\mathrm{CPI} 2005(-1))-0.763 \\
& \text { [4.663] [4.662] [3.237] [-1.583] }
\end{aligned}
$$

$\mathrm{D}(\mathrm{CPI} 2005)=7.452(\mathrm{YIELD}(-1)+0.004 *$ DEBTRATIO $(-1)-0.001 *$ CPI2005 $(-1)-0.080)$

$$
\begin{aligned}
& \text { [0.754] [5.479] [-4.172] } \\
& \text { + 23.790*D(YIELD(-1)) + 0.034*D(DEBTRATIO(-1)) + 0.745*D(CPI2005(-1)) + } 0.335 \\
& \text { [2.323] [0.811] [8.758] [2.283] }
\end{aligned}
$$

Due to the insignificance of the cointegration equation for CPI at the five percent level for the error correction model, we test whether it has a weak exogenous influence on the system by restricting the coefficient of the cointegration equation of CPI to be zero. The Chi-Square test does not allow for rejecting the hypothesis that the cointegration coefficient is zero at a p-value of 0.513 . The residuals of this model are, too, normally distributed with a Jarque-Bera value of 9.686. The cointegration vector is, again, stationary (0.059 in levels with a constant and 0.058 with a constant and trend). We therefore have empirical evidence to conclude that yields have a negative influence, whereas CPI has a positive influence on debt.

A concluding remark of the test series of the unique data set in this section is straightforward: We have found econometric evidence, that Germany's fiscal policy has not been sustainable since 1950 (section 4.2). Sustainability of fiscal policy can only be assumed for the German Empire before 1913, but only if we do not allow for trends in the cointegration relation. In addition, we could not find any empirical evidence for a positive reaction of debt to primary surpluses (section 4.3). Instead, we report evidence that contradicts Fincke and Greiner (2011). The VECM (section 4.4) showed a simultaneous equilibrium. Granger causality and Block exogeneity tests showed that debt is influenced by yields and CPI, but not vice versa.

\section{CONCLUSION}

Public debt in Germany has continuously attracted attention. After the experience of the two World Wars, the German population is quickly alarmed when debt levels appear to be rising to unsustainable levels. This holds particularly for recent years, as Germany's debt-to-GDP ratio has never been higher in peacetime than today. 
In this paper, we analyse sustainability of German public finances from 1872 to 2010. Given the breaks in the data series, in particular those induced by the two World Wars, the main analysis is conducted for the sub-periods 1872-1913 and 1950-2010. In addition to anecdotal historical evidence, we conduct more formal tests on fiscal sustainability. While we cannot reject the hypothesis that fiscal policy was sustainable in the period before the First World War, this only holds if we do not allow for trends in the cointegration relation. The hypothesis of fiscal sustainability for the years 1950 to 2010, on the other hand, must be rejected. After the Second World War, German public finances have become unsustainable.

This evidence leads to the conclusion that public finances in Germany are in dire need of consolidation. In fact, the introduction of the debt brake in the year 2009 is a much needed reaction to this development. Although such fiscal rules always have their loopholes and are necessarily incomplete, they usually have some success in restricting public deficits and debt (Feld and Kirchgässner 2008, Feld and Baskaran 2010). The incompleteness of the German debt brake will have to be addressed in the coming years in order to ensure that fiscal consolidation actually takes place. One shortcoming of the new debt rule requires wider ranging reform, however: The Länder (including their local jurisdictions) not only have huge consolidation requirements, they also do not have the tax autonomy to balance the spending demands on their budgets. The next major reform of the German fiscal constitution should thus allow for more tax autonomy at the sub-federal level.

\section{REFERENCES}

Abbas, S.M., N. Belhocine, A.A. El-Ganainy, M.A. Horton (2010), A Historical Public Debt Database. IMF Working Paper WP/10/245.

Academic Advisory Board at the Federal Minister of Economics and Technology (2008), Zur Begrenzung der Staatsverschuldung nach Art. 115 GG und zur Aufgabe des Stabilitäts- und Wachstumsgesetzes. Gutachten 01/08. Berlin.

Accominotti, O., M. Flandreau, R. Rezzik (2011), The Spread of Empire: Clio and the Measurement of Colonial Borrowing Costs. The Economic History Review 64: 385-407.

Afonso, A. (2005), Fiscal Sustainability: The Unpleasant European Case. FinanzArchiv 61: 19-44.

Afonso, A., J.T. Jalles (2011), A Longer-Run Perspective on Fiscal Stability. School of Economics and Management, Technical University Lisbon, Working Paper 17.

Ahmed, S., J. Rogers (1995), Government Budget Deficits and Trade Deficits. Are Present Value Constraints Satisfied in Long-term Data? Journal of Monetary Economics 36: 351-374.

Auerbach, A.J., J. Gokhale, L.J. Kotlikoff (1991), Generational Accounts: A Meaningful Alternative to Deficit Accounting. Pp. 55-110 in: D. Bradford (ed.), Tax Policy and the Economy 5. Cambridge.

Auerbach, A.J., J. Gokhale, L.J. Kotlikoff (1992), Generational Accounting: A New Approach to Understanding the Effects of Fiscal Policy on Saving. Scandinavian Journal of Economics 94: 303-319.

Balassone, F., D. Franco (2000), Assessing Fiscal Sustainability: A Review of Methods with a View to EMU, Essays presented at the Bank of Italy workshop held in Perugia, 20-22 January 2000. Available at: http://www.bancaditalia.it/studiricerche/convegni/atti/fiscal_sust/i/021-060_balassone_and_franco.pdf (last access on 20 June 2012).

Bank Deutscher Länder (1950), Geschäftsbericht für die Jahre 1948 und 1949. Frankfurt a.M.

Baskaran, T. (2010), On the Link between Fiscal Decentralization and Public Debt in OECD Countries. Public Choice 145, 351-378.

Blanchard, O., G. Illing (2006), Makroökonomie ( $4^{\text {th }}$ ed.). München. 
Bohn, H. (1995), The Sustainability of Budget Deficits in a Stochastic Economy. Journal of Money Credit and Banking 27: 257-271.

Bohn, H. (1998), The Behaviour of U.S. Public Debt and Deficits. Quarterly Journal of Economics 113: 949-963.

Bohn, H. (2008), The Sustainability of Fiscal Policy in the United States. Pp. 15-49 in: R. Neck, J. Sturm (eds.), Sustainability of Public Debt. Cambridge/London.

Bordo, M.D., A.J. Schwartz (1999), Under What Circumstances, Past and Present, Have International Rescues of Countries in Financial Distress Been Successful? Journal of International Money and Finance 18: 683-708.

Bravo, A., A. Silvestre (2002), Intertemporal Sustainability of Fiscal Policies: Some Tests for European Countries. European Journal of Political Economy 18: 517-528.

Buchanan, J.M., G. Tullock (1962), The Calculus of Consent. Ann Arbor.

Burhop, C., G. Wolff (2005), A Compromise of German Net National Product, 1851-1913, and Its Implications for Growth and Business Cycles. Journal of Economic History 65: 613-657.

Burret, H.T., L.P. Feld, E.A. Köhler (2013), Sustainability of Public Debt in Germany - Historical Considerations and Time Series Evidence. Jahrbücher für Nationalökonomie und Statistik (Journal of Economics and Statistics) $233 / 3$, to be published.

Cheung, Y.-W., K.S. Lai (1995), Lag Order and Critical Values of the Augmented Dickey-Fuller Test. Journal of Business and Economic Statistics 13: 277-280.

Cohn, L.R. (1997), Fiscal Policy in Germany During the Great Depression. Pp. 261-283 in: J. Komlos, S.M. Eddie (eds.), Selected Cliometric Studies on German Economic History. Stuttgart.

Deutsche Bundesbank (1976), Deutsches Geld- und Bankwesen in Zahlen 1876-1975. Frankfurt a.M.

Deutsche Bundesbank (2011), The Debt Brake in Germany - Key Aspects and Implementation. Monthly Report, October.

Deutsche Bundesbank (2012), Zeitreihe UJFB99. Verbraucherpreisindex. Available at: http://www.bundesbank.de/cae/servlet/CsvDownload?tsld=BBK01.UJFB99\&its_csvFormat=de\&mode=its (last access on 20 June 2012).

Domar, E.D. (1944), The Burden of the Debt and International Income. American Economic Review 34: 789-827.

Eheberg, K.T. (1892), Finanzverhältnisse europäischer Großstädte. Jahrbücher für Nationalökonomie und Statistik (Journal of Economics and Statistics) 58: 906-918.

Elliot, G., C. Kearny (1988), The Intertemporal Government Budget Constraint and Tests for Bubbles. Research Discussion Paper 8809, Reserve Bank of Australia.

Engle, R.F., C.W. Granger (1987), Cointegration and Error-Correction: Representation, Estimation, and Testing. Econometrica 55: 251-276.

Feld, L.P., T. Baskaran (2010), Federalism, Budget Deficits and Public Debt: On the Reform of Germany's Fiscal Constitution. Review of Law and Economics 6(3): 365-393.

Feld, L.P., G. Kirchgässner (2001), Does Direct Democracy Reduce Public Debt? Evidence from Swiss Municipalities. Public Choice 109, 347-370.

Feld, L.P., G. Kirchgässner (2008), On the Effectiveness of Debt Brakes: The Swiss Experience. Pp. 223-255 in: R. Neck, J.-E. Sturm (eds.), Sustainability of Public Debt. Cambridge.

Feld, L.P., C.A. Schaltegger (2010), Political Stability and Fiscal Policy: Time Series Evidence for the Swiss Federal Level since 1849. Public Choice 144: 505-534.

Fincke, B., A. Greiner (2009), Public Debt and Economic Growth. Heidelberg.

Fincke, B., A. Greiner (2011), Do Large Industrialized Economies Pursue Sustainable Debt Policies? A Comparative Study for Japan, Germany and the United States. Japan and the World Economy 23, 203-213.

Gerloff, W. (1913), Die Finanz- und Zollpolitik des Deutschen Reiches. Jena.

German Council of Economic Experts (2005), Die Chance nutzen - Reformen mutig voranbringen. Jahresgutachten 2005/2006. Wiesbaden.

German Council of Economic Experts (2011), Verantwortung für Europa wahrnehmen. Jahresgutachten 2011/2012. Wiesbaden.

Glasemann, H.G. (1993), Deutschlands Auslandsanleihen 1924-1945. Wiesbaden.

Glynn, J., N. Perera, R. Verma (2007), Unit Root Tests and Structural Breaks: A Survey with Applications. Revista de Métodos Cuantitativos para la Economía y la Empresa (Journal of Quantitative Methods for Economics and Business Administration) 3: 63-79.

Goldschmidt, N., E. Köhler (2008), Die Ursprünge der Sozialen Marktwirtschaft und die Währungsreform von 1948. Pp. 82-98 in: Hessisches Wirtschaftsarchiv (ed.), Beiträge zur hessischen Wirtschaftsgeschichte 4. Darmstadt.

Greiner, A., G. Kauermann (2007), Sustainability of US Public Debt: Estimating Smoothing Spline Regressions. Economic Modelling 24: 350-364. 
Greiner, A., G. Kauermann (2008), Evidence for Germany and Italy Using Penalized Spline Smoothing. Economic Modelling 25: 1144-1154.

Greiner A., U. Köller, W. Semmler (2006), Testing the Sustainability of German Fiscal Policy: Evidence for the Period 1960-2003. Empirica 33: 127-140.

Grilli, V. (1988), Seigniorage in Europe. National Bureau of Economic Research (NBER), Working Paper No. 2778.

Hagen, J. von, I.J. Harden (1995), Budget Processes and Commitment to Fiscal Discipline. European Economic Review 39, 771-779.

Hakkio, G., M. Rush (1991), Is the Budget Deficit Too Large? Economic Inquiry 29: 429-445.

Haller, H. (1976), Die Rolle der Staatsfinanzen für den Inflationsprozeß. Pp. 115-155 in: Deutsche Bundesbank (ed.), Währung und Wirtschaft in Deutschland 1876-1975. Frankfurt a.M.

Hamilton, J.D. (1994), Times Series Analysis. Princeton.

Hamilton, J.D., M. Flavin (1986), On the Limitations of Government Borrowing: A Framework for Empirical Testing. American Economic Review 76: 808-819.

Hansmeyer, K.-H., R. Caesar (1976), Kriegswirtschaft und Inflation (1936-1948). Pp. 367-429 in: Deutsche Bundesbank (ed.), Währung und Wirtschaft in Deutschland 1876-1975. Frankfurt a.M.

Haug, A. (1995), Has Federal Budget Deficit Policy Changed in Recent Years? Economic Inquiry 33: 104-118.

Heckel, M. von (1900), Beiträge zur vergleichenden Finanzstatistik europäischer Großstaaten im Jahre 1898. Jahrbücher für Nationalökonomie und Statistik (Journal of Economics and Statistics) 74: 34-61.

Hefeker, C. (2001), The Agony of Central Power: Fiscal Federalism in the German Reich. European Review of Economic History 5: 119-142.

Helfferich, K.T. (1916), Stenographische Berichte der Verhandlungen des Reichstags Vol. 306. Available at: http://www.reichstagsprotokolle. de/Blatt_k13_bsb00003402_00000.html (last access on 20 June 2012).

Hoffmann, W.G. (1965), Das Wachstum der deutschen Wirtschaft seit der Mitte des 19. Jahrhunderts. Heidelberg.

Holtfrerich, C.-L. (1996), Bewältigung der deutschen Staatsbankrotte 1918 und 1945. Pp. 25-57 in: E. Kantzenbach (ed.), Staatsüberschuldung: Referate gehalten auf dem Symposium der Joachim-Jungius-Gesellschaft der Wissenschaften Hamburg am 9. und 10. Februar 1996. Göttingen.

Homer, S. (1963/77), A History of Interest Rates ( $2^{\text {nd }}$ ed.). New Jersey.

Johansen, S. (1988), Statistical Analysis of Cointegration Vectors. Journal of Economic Dynamics and Control 12: 231-254.

Kirchgässner, G., S. Prohl (2008), Sustainability of Swiss Fiscal Policy. Swiss Journal of Economics and Statistics 144: 57-83.

Kirchgässner, G., J. Wolters (2006), Einführung in die moderne Zeitreihenanalyse. München.

Kitterer, W. (2007), Nachhaltige Finanz- und Investitionspolitik der Bundesländer. Perspektive der Wirtschaftspolitik 8: 53-83.

Kremers, J. (1988), The Long-Run Limits of U.S. Federal Debt. Economics Letters 28: 259-262.

Krogstrup, S., S. Wälti (2008), Do Fiscal Rules Cause Budgetary Outcomes? Public Choice 136: 123-138.

Kwiatkowski, D., P.C.B. Phillips, P. Schmidt, Y. Shin (1992), Testing the Null Hypothesis of Stationarity against the Alternative of a Unit Root. Journal of Econometrics 54: 159-178.

Länderrat des Amerikanischen Besatzungsgebiets (1949), Statistisches Handbuch von Deutschland 1928-1944. München.

Leeper, E. (1991), Equilibria under 'Active' and 'Passive' Monetary Policies. Journal of Monetary Economics 27: 129-147.

Liu, P., E. Tanner (1995), Intertemporal Solvency and Breaks in the U.S. Deficit Process: A Maximum-likelihood Cointegration Approach. Applied Economics Letters 2: 231-235.

Lucas, R. (1978), Asset Prices in an Exchange Economy. Econometrica 46: 1429-1445.

MacDonald, R. (1992), Some Tests of the Government's Intertemporal Budget Constraint Using U.S. Data. Applied Economics 24: 1287-1292.

Maddisson, A. (2010), Statistics on World Population, GDP and Per Capita GDP, 1-2008 AD. Available at: http://www.ggdc.net/maddison/Historical_Statistics/horizontal-file_02-2010.xls (last access on 29 November 2012)

Mendoza, E., J.D. Ostry (2008), International Evidence on Fiscal Solvency: Is Fiscal Policy „Responsible“? Journal of Monetary Economics 55: 1081-1093.

Mitchell, B.R. (2007), International Historical Statistics: Europe 1750-2005 (6 ${ }^{\text {th }}$ ed.). New York.

Mückl, W.J. (1985), Langfristige Grenzen der öffentlichen Kreditaufnahme. Jahrbücher für Nationalökonomie und Statistik (Journal of Economics and Statistics) 200: 565-581

Neck, R., J.E. Sturm (2008), Sustainability of Public Debt: Introduction and Overview. Pp. 1-13 in: R. Neck, J.E. Sturm (eds.), Sustainability of Public Debt. Cambridge. 
Neugebauer, W. (2000), Handbuch der preussischen Geschichte, Band 3 Vom Kaiserreich zum 20. Jahrhundert und große Themen der Geschichte Preußens. Berlin.

Neumark, F. (1976), Die Finanzpolitik in der Zeit vor dem I. Weltkrieg. Pp. 57-111 in Deutsche Bundesbank (ed.), Währung und Wirtschaft in Deutschland 1876-1975. Frankfurt a.M.

Obstfeld, M., A.M. Taylor (2003), Sovereign Risk, Credibility and the Gold Standard: 1879-1913 versus 19251931. Economic Journal 113: 241-275.

Payne, J. (1997), International Evidence on the Sustainability of Budget Deficits. Applied Economics Letters 12: 775-779.

Petzina, D. (1986), Kommunale Finanzen und Handlungsspielräume in der Weltwirtschaftskrise: Das Beispiel der Stadt Bochum. Pp. 231-254 in: H.-J. Teuteberg (ed.), Stadtwachstum, Industrialisierung, sozialer Wandel. Berlin.

Pfleiderer, O. (1976), Die Reichsbank in der Zeit der großen Inflation, die Stabilisierung der Mark und die Aufwertung von Kapitalforderungen. Pp. 157-202 in: Deutsche Bundesbank (ed.), Währung und Wirtschaft in Deutschland 1876-1975. Frankfurt a.M.

Plumpe, W. (2010), Wirtschaftskrise: Geschichte und Gegenwart. München.

Polito, V., M. Wickens (2011), Assessing the fiscal stance in the European Union and the United States, 19702011. Economic Policy 26: 599-647.

Quintos, C. (1995), Sustainability of the Deficit Process with Structural Shifts. Journal of Business \& Economic Statistics 13: 409-417.

Reinhart, C.M., K.S. Rogoff (2009), This Time Is Different: Eight Centuries of Financial Folly. Princeton.

Ricardo, D. (1817/1932), Principles of Political Economy and Taxation. London.

Richter, R. (1998), Deutsche Geldpolitik 1948-1998. Tübingen.

Ritschl, A. (2002), Deutschlands Krise und Konjunktur. Binnenkonjunktur, Auslandsverschuldung und Reparationsproblem zwischen Dawes-Plan und Transfersperre 1924-1934, Berlin.

Ritschl, A., M. Spoerer (1997), Das Bruttosozialprodukt in Deutschland nach den amtlichen Volkseinkommensund Sozialstatistiken 1901-1995. Pp. 28-54 in Lothar Baar et al. (ed.), Jahrbuch für Wirtschaftsgeschichte 1997-2. Berlin.

Roesler, K. (1967), Die Finanzpolitik des Deutschen Reichs im Ersten Weltkrieg. Duncker und Humblot, Berlin.

Sargent, T.J., N. Wallace (1981), Some Unpleasant Monetarist Arithmetic. Federal Reserve Bank of Minneapolis Quarterly Review 5: 1-17.

Schacht, H. (1945), Interrogation of Schacht 16 October 1945. Donovan Nuremberg Trials Collection XVI. Available at: http://library2.lawschool.cornell.edu/donovan/pdf/Batch_7/Vol_XVI_48_04_01.pdf (last access on 20 June 2012).

Schaltegger, C.A., L.P. Feld (2009a), Do Large Cabinets Favor Large Governments?, Evidence on the Fiscal Commons Problem for Swiss Cantons. Journal of Public Economics 93: 35-47.

Schaltegger, C.A., L.P. Feld (2009b), Are Fiscal Adjustments Less Successful in Decentralized Governments? European Journal of Political Economy 25: 115-123.

Schiller, K. (1936), Arbeitsbeschaffung und Finanzordnung in Deutschland. Zum Wirtschaftlichen Schicksal Europas: Arbeiten zur deutschen Problematik. Berlin.

Schremmer, E. (1994), Steuern und Staatsfinanzen während der Industrialisierung Europas. Berlin.

Schularick, M., A.M. Taylor (2012), Credit Booms Gone Bust: Monetary Policy, Leverage Cycles and Financial Crises, 1870-2008. American Economic Review 102: 1029-1061.

Schumpeter, J.A. (1952), Aufsätze zur Ökonomischen Theorie. Tübingen.

Sims, C.A. (1994), A Simple Model for Study of the Determination of the Price Level and the Interaction of Monetary and Fiscal Policy. Economic Theory 4: 381-399.

Smith, G., S. Zin (1991), Persistent Deficits and the Market Value of Government Debt. Journal of Applied Econometrics 6: 31-44.

Statistisches Bundesamt (2011a), Schulden der öffentlichen Haushalte: Finanzen und Steuern, 2010 Fachserie 14 Reihe 5 . Wiesbaden.

Statistisches Bundesamt (2011b), Finanzen und Steuern - Rechnungsergebnisse des öffentlichen Gesamthaushalts 2008, Fachserie 14 Reihe 3.1. Wiesbaden.

Statistisches Bundesamt (2011c), Entwicklung der öffentlichen Finanzen in Deutschland. Available at: https://www.destatis.de/DE/ZahlenFakten/Indikatoren/LangeReihen/SteuernFinanzen/Irfin01.html (last access on 20 June 2012).

Statistisches Bundesamt (2012), Volkswirtschaftliche Gesamtrechnungen - Bruttoinlandsprodukt, Bruttonationaleinkommen, Volkseinkommen - Lange Reihe ab 1950, 2011. Available at: https://www.destatis.de/DE/ZahlenFakten/GesamtwirtschaftUmwelt/VGR/Inlandsprodukt/Tabellen/Volkse inkommen1950.xls?_blob=publicationFile (last access on 20 June 2012). 
Stegarescu, D. (2005), Centralization Tendencies in the Public Sector in Germany. Zentrum für Europäische Wirtschaftsforschung (ZEW) Discussion Paper 46.

Tanner, E., P. Liu (1994), Is the Budget Deficit Too Large? Some Further Evidence. Economic Inquiry 32: 511518.

Terhalle, F. (1952), Geschichte der deutschen öffentlichen Finanzwirtschaft vom Beginn des 19. Jahrhunderts bis zum Schlusse des zweiten Weltkrieges. Pp. 273-326 in: W. Gerloff, F. Neumark (eds.), Handbuch der Finanzwissenschaft Vol. 1 ( $2^{\text {nd }}$ ed.). Tübingen.

Trehan, B., C.E. Walsh (1988), Common Trends, Intertemporal Budget Balance, and Revenue Smoothing. Journal of Economic Dynamics and Control 12: 425-444.

Trehan, B., C.E. Walsh (1991), Testing Intertemporal Budget Constraints: Theory and Applications to the US Federal Budget and Current Account Deficit. Journal of Money, Credit and Banking 23: 206-223.

Velasco, A. (2000), Debts and Deficits with Fragmented Fiscal Policymaking. Journal of Public Economics 76 : 105-125.

Vogler, R.U., J. Baumberger, H.R. Reginbogin, J. Spiller (eds.) (2012), Financial Markets of Neutral Countries in World War II. Association for Financial History Switzerland und Principality of Liechtenstein. Zürich.

Weingast, B.R., K.A. Shepsle, C. Johnson (1981), The Political Economy of Benefits and Costs: A Neoclassical Approach to Distributive Politics. Journal of Political Economy 89: 642-664.

Wilcox, D. (1989), The Sustainability of Government Deficits: Implications of the Present-Value Borrowing Constraint. Journal of Money, Credit, and Banking 21: 291-306.

Woodford, M. (1995), Price Level Determinacy Without Control of a Monetary Aggregate. Carnegie-Rochester Conference Series on Public Policy 43: 1-46.

Zivot, E., K. Andrews (1992), Further Evidence On The Great Crash, The Oil Price Shock, and The Unit Root Hypothesis. Journal of Business and Economic Statistics 10: 251-270. 


\section{APPENDIX}

\section{A.1 Data}

\begin{tabular}{|c|c|c|c|c|}
\hline Variable & Name & Description & Source & \\
\hline CPI & $\begin{array}{l}\text { cpi19913 } \\
\text { cpi2005 }\end{array}$ & $\begin{array}{l}\text { consumer price index }(1913 / 14=100) \text {. } \\
\text { consumer price index }(2005=100) .\end{array}$ & $\begin{array}{l}\text { 1877-1944: } \\
\text { 1949-2010: }\end{array}$ & $\begin{array}{l}\text { Deutsche Bundesbank (1976) } \\
\text { Deutsche Bundesbank (2012) }\end{array}$ \\
\hline $\begin{array}{l}\text { General gov- } \\
\text { ernment debt }\end{array}$ & debtgen & $\begin{array}{l}\text { total public debt in million Mark/Euro. } \\
\text { Including Reich/Bundesrepublik, states/Bundesländer, } \\
\text { municipalities (where available), most public funds. }\end{array}$ & 1850-1949: & $\begin{array}{l}\text { Own calculations(federal debt }+ \\
\text { regional debt +municipal debt) } \\
\text { Statistisches Bundesamt (2011a) }\end{array}$ \\
\hline Federal debt & debtc & $\begin{array}{l}\text { debt of the Reich/Bundesrepublik in million Mark/Euro. } \\
\text { Fiscal year until 1945: } 31^{\text {st } M a r c h, ~ a f t e r w a r d s ~} 31^{\text {st }} \text { December. } \\
1914-1944 \text { including Mefo bills. } \\
1949 \text { including equalisation claims (Ausgleichsforderungen). }\end{array}$ & $\begin{array}{l}\text { 1850-1913: } \\
\text { 1914-1944: } \\
\text { 1949: } \\
\text { 1950-2010: }\end{array}$ & $\begin{array}{l}\text { Hoffmann (1965) } \\
\text { Deutsche Bundesbank (1976) } \\
\text { Bank deutscher Länder (1950) } \\
\text { Statistisches Bundesamt (2011a) }\end{array}$ \\
\hline Regional debt & debtl & $\begin{array}{l}\text { Debt of the states/Bundesländer in million Mark/Euro. } \\
\text { Fiscal year until 1945: } 31^{\text {st }} \text { March, afterwards } 31^{\text {st December. }}\end{array}$ & $\begin{array}{l}\text { 1850-1913: } \\
\text { 1914-1944: } \\
\text { 1950-2010: }\end{array}$ & $\begin{array}{l}\text { Hoffmann (1965) } \\
\text { Deutsche Bundesbank (1976) } \\
\text { Statistisches Bundesamt (2011a) }\end{array}$ \\
\hline Municipal debt & debtm & $\begin{array}{l}\text { Municipal debt in million Mark/Euro. } \\
\text { Fiscal year until } 1945: 31^{\text {st }} \text { March, afterwards } 31^{\text {st }} \text { December. } \\
\text { 1850-1913 including debt with Sparkassen and other local } \\
\text { authority obligations. }\end{array}$ & $\begin{array}{l}\text { 1850-1913: } \\
\text { 1914 } \\
\text { 1928-1940: } \\
\text { 1950-2010: }\end{array}$ & $\begin{array}{l}\text { Hoffmann (1965) } \\
\text { Schremmer (1994) } \\
\text { Deutsche Bundesbank (1976) } \\
\text { Statistisches Bundesamt (2011a) }\end{array}$ \\
\hline Debt service & dservice & $\begin{array}{l}\text { Interest service on total public debt in million Mark/Euro. } \\
\text { 1880-1913 for Reich and Prussia, Württemberg, Baden, } \\
\text { Bavaria, Saxony and Hamburg. }\end{array}$ & $\begin{array}{l}\text { 1880-1913: } \\
\text { 1950-2010: }\end{array}$ & $\begin{array}{l}\text { Accominotti et al. (2011) } \\
\text { inquired at Statistisches Bundesamt }\end{array}$ \\
\hline Fiscal deficit & deficit & Public deficit in million Mark/Euro & $\begin{array}{l}\text { 1871-1913: } \\
\text { 1950-2010: }\end{array}$ & $\begin{array}{l}\text { own calculation: debtgen(t)-debtgen(t- } \\
\text { 1) } \\
\text { inquired at Statistisches Bundesamt }\end{array}$ \\
\hline $\begin{array}{l}\text { Public expendi- } \\
\text { tures }\end{array}$ & Exp & $\begin{array}{l}\text { General ordinary and extraordinary expenditures (in million } \\
\text { Mark/Euro). } \\
\text { 1871-1879, 1919-1925, 1933-1944 without states. } \\
1920-1923 \text { only current expenditures of the Reich. }\end{array}$ & $\begin{array}{l}\text { 1871-1879, } \\
\text { 1924: } \\
\text { 1880-1913: } \\
\text { 1914-1919: } \\
\text { 1920-1923: } \\
\text { 1925-1932: } \\
\text { 1933-1944: } \\
\text { 1950: } \\
\text { 1951-2010: }\end{array}$ & $\begin{array}{l}\text { Mitchell (2007) } \\
\text { Accominotti et al. (2011) } \\
\text { Roesler (1967) } \\
\text { Haller (1976) } \\
\text { Ritschl (2002) } \\
\text { Länderrat des Amerikanischen Besat- } \\
\text { zungsgebiets (1949) } \\
\text { Statistisches Bundesamt (2011b) } \\
\text { Statistisches Bundesamt (2011c) }\end{array}$ \\
\hline Nominal GDP & nomgdp & $\begin{array}{l}\text { in local currency, current prices. } \\
\text { Nominal GDP in local currency, current prices. } \\
\text { 1914-1924: Real GDP (in 1913 prices) estimated by } \\
\text { Ritschl and Spoerer (1997), GDP } \\
\text { deflator as measured by CPI1913. }\end{array}$ & $\begin{array}{l}\text { 1851-1913: } \\
\text { 1914-1924: } \\
\text { 1924-1939: } \\
\text { 1940-1944, } \\
\text { 1946-1950: } \\
\text { 1950-2010: }\end{array}$ & $\begin{array}{l}\text { Burhop and Wolff (2005), kindly made } \\
\text { available by Schularick. } \\
\text { Own calculations } \\
\text { Schularick and Taylor (2012) } \\
\text { Ritschl and Spoerer (1997) } \\
\text { Statistisches Bundesamt (2012) }\end{array}$ \\
\hline Public revenues & rev & $\begin{array}{l}\text { General ordinary and extraordinary revenue (in million } \\
\text { Mark/Euro). } \\
1871-1879,1919-1925,1933-1949 \text { without states; } 1920- \\
1923 \text { only current expenditures. }\end{array}$ & $\begin{array}{l}\text { 1871-1879, } \\
\text { 1946-1949: } \\
\text { 1880-1913: } \\
\text { 1914-1919: } \\
\text { 1920-1923: } \\
\text { 1925-1932: } \\
\text { 1933-1944: } \\
\text { 1950: } \\
1951-2010:\end{array}$ & $\begin{array}{l}\text { Mitchell (2007) } \\
\text { Accominotti et al. (2011) } \\
\text { Roesler (1967) } \\
\text { Haller (1976) } \\
\text { Ritschl (2002) } \\
\text { Länderrat des Amerikanischen Besat- } \\
\text { zungsgebiets (1949) } \\
\text { Statistisches Bundesamt (2011b) } \\
\text { Statistisches Bundesamt (2011c) }\end{array}$ \\
\hline Primary deficit & pdeficit & $\begin{array}{l}\text { Primary deficit, i.e. budget deficit or surplus after deducting } \\
\text { interest payments (in million Mark/Euro). }\end{array}$ & 1950-2010: & deficit-dservice \\
\hline Real GDP & rgdp & constant prices of 1990, Int. GK\$ & $\begin{array}{l}\text { 1850-2008: } \\
\text { 2009-2010: }\end{array}$ & $\begin{array}{l}\text { Maddison (2010) } \\
\text { Schularick and Taylor (2012) }\end{array}$ \\
\hline Bond yields & yield & $\begin{array}{l}\text { Long term government bond yields, } 5 \text { year or } 10 \text { year } \\
\text { maturity. } \\
\text { 1850-1869: computed as average of two Prussian and one } \\
\text { Bavarian bond yields }\end{array}$ & $\begin{array}{l}\text { 1850-1869: } \\
\text { 1870-2008: } \\
\text { 2009-2010: }\end{array}$ & $\begin{array}{l}\text { Homer (1963/77) } \\
\text { Schularick and Taylor (2012) } \\
\text { IMF International Financial Statistics }\end{array}$ \\
\hline
\end{tabular}


A.2 Comparison of Estimated Debt Ratios (\% of GDP), 1914-1924

\begin{tabular}{llllllllllll}
\hline & $\mathbf{1 9 1 4}$ & $\mathbf{1 9 1 5}$ & $\mathbf{1 9 1 6}$ & $\mathbf{1 9 1 7}$ & $\mathbf{1 9 1 8}$ & $\mathbf{1 9 1 9}$ & $\mathbf{1 9 2 0}$ & $\mathbf{1 9 2 1}$ & $\mathbf{1 9 2 2}$ & $\mathbf{1 9 2 3}$ & $\mathbf{1 9 2 4}$ \\
\hline Our estimates* & 80.50 & 88.70 & 105.68 & 124.81 & 132.78 & 110.84 & 58.30 & 57.39 & 91.35 & 2.86 & 4.39 \\
Holtfrerich (1996) & - & - & - & - & 180 & 127 & - & - & - & - & - \\
\hline Schularick** & 47.92 & 61.82 & 98.11 & 128.94 & 160.4 & 133.13 & 43.41 & 42.44 & 10.31 & - & - \\
\hline
\end{tabular}

*Our estimates include the Bundesländer until 1919. **Data kindly made available by Schularick, referring to Niall Ferguson.

A.3 Public Debt as Percentage of GDP in nine OECD countries, 1880-2010

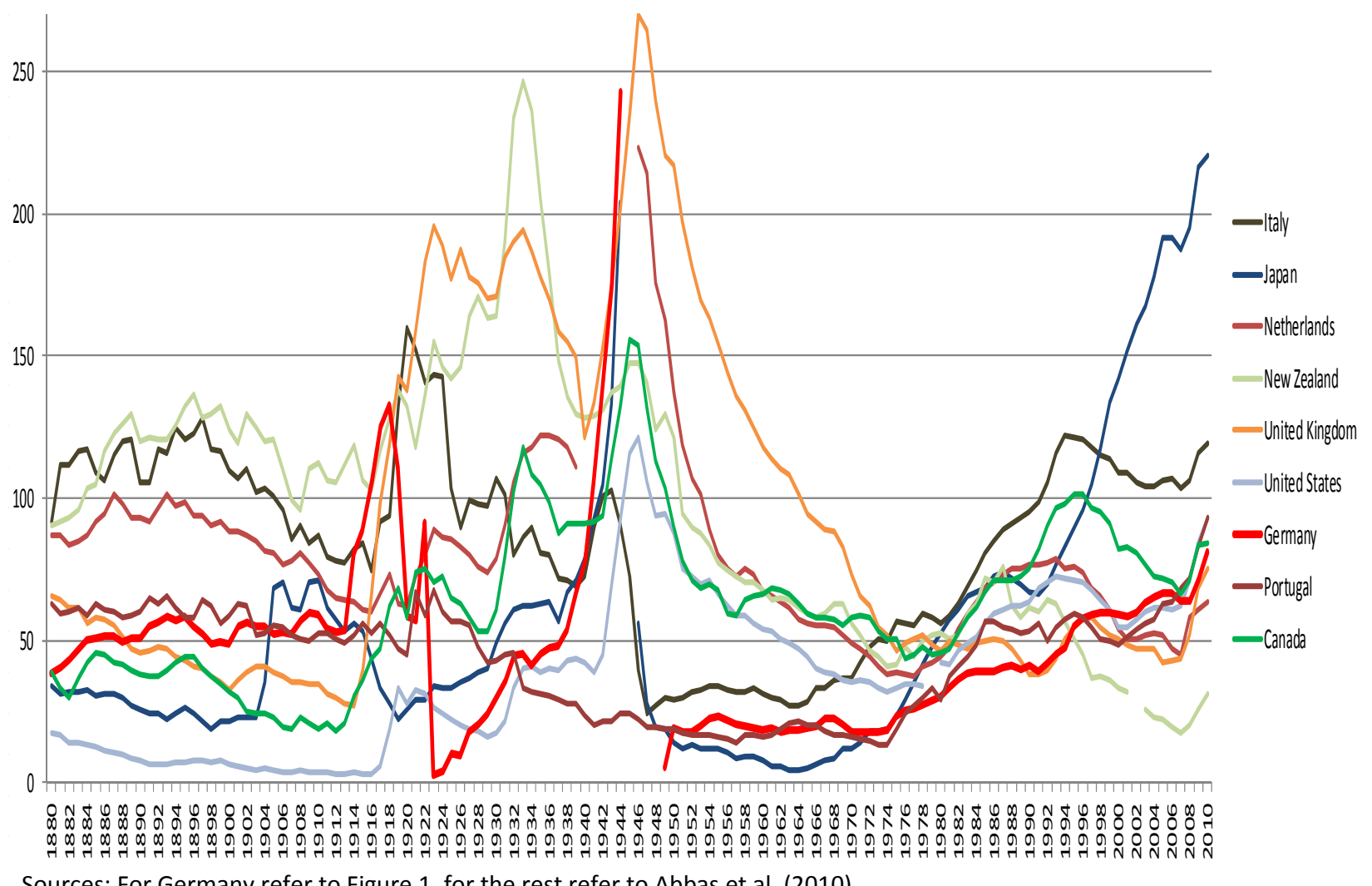

Sources: For Germany refer to Figure 1, for the rest refer to Abbas et al. (2010). 